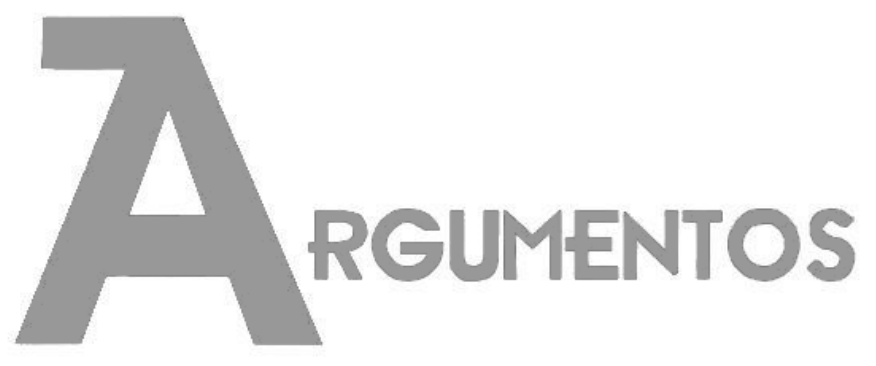

Vol. 18, n. 2, jul./dez. 2021 ISSN: 2527-2551 (online)

\title{
"Revolução com espírito empresarial": a criação do Clube dos 13 e a modernização do futebol na Folha de S. Paulo
}

\author{
Sérgio Settani Giglio ${ }^{1}$ \\ João Manuel Casquinha Malaia Santos²
}

Recebido em: 01/04/2021

Aprovado em: 19/05/2021

Resumo: A partir de uma análise do jornal Folha de S. Paulo buscamos compreender os fatos relacionados à criação do Clube dos 13 em 1987. Essa criação, no entanto, foi permeada de disputas de poder que envolveu a Confederação Brasileira de Futebol (CBF) e o Clube dos 13. Nessa disputa foram polarizadas visões maniqueístas que colocavam de um lado, a CBF e seu atraso diante do Clube dos 13 e sua visão empresarial. A análise da Folha de S. Paulo também seguia essa linha, em que a mudança do futebol brasileiro teria que ser feita por meio de uma gestão empresarial. Concluímos que os discursos apresentados, tanto pela Folha quanto pelo Clube dos 13 , defendiam uma modernização conservadora e contribuiu para a manutenção de monopólios no futebol brasileiro.

Palavras-chave: Copa União; Campeonato Brasileiro; CBF; Clube dos 13; Folha de S. Paulo.

\section{"Revolución con espíritu empresarial": la creación del Clube de los 13 y la modernización del fútbol en Folha de $\mathrm{S}$. Paulo}

Resumen: A partir de un análisis del periódico Folha de S. Paulo buscamos entender los hechos relacionados con la creación del Clube dos 13 en 1987. Esta creación, sin embargo, estuvo permeada por disputas de poder que involucraron a la Confederación Brasileña de Fútbol (CBF) y al Clube dos 13. En esta disputa se polarizaron las visiones maniqueas, que colocaron de un lado a la CBF y su atraso frente al Clube dos 13 y su visión empresarial. El análisis de Folha de $\mathrm{S}$. Paulo también siguió esta línea, en la que el cambio del fútbol brasileño tendría que hacerse mediante una gestión empresarial. Concluimos que los discursos presentados, tanto por Folha como por el Clube dos 13, defendieron una modernización conservadora y contribuyeron al mantenimiento de los monopolios en el fútbol brasileño.

\footnotetext{
${ }^{1}$ Docente do Departamento de Educação Física e Humanidades e do Programa de Pós-Graduação da Faculdade de Educação Física da UNICAMP. E-mail: sergio@fef.unicamp.br. ORCID: https://orcid.org/0000-0002-3190-0859.

2 Docente do Departamento de História e do Programa de Pós-Graduação em História da Universidade Federal de Santa Maria. E-mail: jmalaia@gmail.com. ORCID: https://orcid.org/0000-0001-7154-3860.
} 
Dossiê | "Revolução com espírito empresarial": a criação do Clube dos 13 e a modernização do futebol na Folha de S. Paulo (GIGLIO, Sérgio Settani; SANTOS, João Manuel Casquinha Malaia)

Palabras clave: Copa Unión; Campeonato Brasileño; CBF; Clube dos 13; Folha de S. Paulo.

\title{
"Revolution with a business spirit": the creation of the Clube of 13 and the soccer modernization in Folha de S. Paulo
}

\begin{abstract}
From an analysis of the Folha de S. Paulo newspaper we seek to understand the facts related to the creation of Clube dos 13 in 1987. This creation, however, was permeated by power disputes that involved the Brazilian Football Confederation (CBF) and the Clube dos 13. In this dispute Manichean visions were polarized, placing on one side the CBF and its backwardness before the Clube dos 13 and its business vision. The Folha de S. Paulo's analysis also followed this line, in which the change in Brazilian football would have to be made through a business management. We conclude that the discourses presented, both by Folha and Clube dos 13, defended a conservative modernization and contributed to the maintenance of monopolies in Brazilian football.
\end{abstract}

Keywords: Union Cup; Brazilian Championship; CBF; Clube dos 13; Folha de S. Paulo.

Em 1987, os presidentes de 13 clubes de futebol do Brasil (Atlético Mineiro, Bahia, Botafogo, Corinthians, Cruzeiro, Flamengo, Fluminense, Grêmio, Internacional, Palmeiras, Santos, São Paulo e Vasco da Gama) insatisfeitos com a gestão da Confederação Brasileira de Futebol (CBF) do futebol resolveram se juntar em busca de reorganizar o futebol nacional. Nascia dessa iniciativa o Clube dos 13 , que tinha a intenção de organizar uma liga de futebol desvinculada da CBF. O discurso adotado pelos dirigentes desses clubes e por boa parte da imprensa de cidades como São Paulo e Rio de Janeiro 3 era de que a proposta desse grupo pretendia "revolucionar" o futebol brasileiro por meio de utilização de procedimentos mais "empresariais".

O então presidente da CBF, Octávio Pinto Guimarães iniciava a sua participação no programa Roda Viva da TV Cultura, em 1986, com a seguinte afirmação: “Quando eu assumi a presidência da CBF eu sabia que o futebol brasileiro precisava de muita coisa, precisava ser sacudido, precisava ser mudado. E evidentemente isso não se faz da noite para o dia, nem de uma hora para outra...". ${ }^{4}$ Os desafios apontados por Octávio

\footnotetext{
${ }^{3}$ Para conferir o discurso dos jornais O Globo e Jornal do Brasil, ver Helal (1997).

${ }^{4}$ Entrevista de Octávio Pinto Guimarães para o programa Roda Viva, da TV Cultura, em 10/11/1986. Disponível em: https://rodaviva.fapesp.br/materia_busca/359/octavio\%20guimar\%E3es\%20pinto/entrevistados/octavi o_pinto_guimaraes_1986.htm. Acesso em 10 de abril de 2021. O programa, exibido desde setembro daquele ano, se propunha a ser "um lugar privilegiado de debate sobre assuntos públicos na televisão brasileira" (SILVA, 2011, p. 49). O programa, exibido desde setembro daquele ano, se propunha a ser "um lugar privilegiado de debate sobre assuntos públicos na televisão brasileira" (SILVA, 2011, p. 49).
} 
Dossiê | "Revolução com espírito empresarial": a criação do Clube dos 13 e a modernização do futebol na Folha de S. Paulo (GIGLIO, Sérgio Settani; SANTOS, João Manuel Casquinha Malaia)

Guimarães versavam também a respeito do campeonato brasileiro de 1986 que passava por um problema de inchaço.

Desde a criação do Campeonato Brasileiro, em plena ditadura militar (em 1971), esta competição foi usada como mais um dos muitos instrumentos de adesão de parcelas significativas da população ao regime. Em um processo que envolveu a construção de inúmeros gigantescos estádios em capitais do Centro-Oeste, Nordeste e Norte do país, o Campeonato Brasileiro passou a receber equipes convidadas destas cidades (SANTOS e FORTES, 2021). Estes e outros arranjos políticos fizeram com que a primeira divisão chegasse a 94 clubes em 1979.

Nos anos 1980, a CBF passou a tentar fazer várias fórmulas diferentes visando diminuir esse inchaço, criando uma série de questões entre quem deveria ficar e quem deveria sair da elite do futebol. Assim, em 1986, o campeonato teve a participação de 80 clubes, divididos em 8 grupos, passando para a segunda fase 32 clubes. Recebendo pressão dos times, o Conselho Nacional de Desportos (CND) e a CBF definiram que o campeonato também seria classificatório para o do ano seguinte que seria disputado com 24 clubes. Porém, vários clubes acionaram a Justiça e conseguiram o direito de participar do campeonato do ano seguinte (SANTOS, 2013). O próprio Octávio Guimarães Pinto entendia que o campeonato de 1986 seria traumático, pois muitos clubes que participaram da edição deste ano não estariam na primeira divisão em 1987. Segundo ele, coube à sua gestão fazer uma revolução "porque nenhum dos meus antecessores ousou sequer tentar fazer essa divisão dos clubes em três divisões no futebol brasileiro". ${ }^{5}$

Nas últimas décadas, o futebol brasileiro produziu um discurso que oscila entre ser o Brasil o "país do futebol", fato chancelado pelo número de conquistas da Copa do Mundo de futebol masculina; ora por uma condição de atraso e "amadorismo" de seus dirigentes. Entre esses discursos há uma série de pontos de inflexão que, em busca de uma modernização, acabou por transformar o futebol nacional.

Desse modo, nosso recorte estará focado em 1987 por corresponder ao ano da criação e implementação do Clube dos 13 no futebol nacional. Tomamos esse momento

\footnotetext{
${ }^{5}$ Entrevista de Octávio Pinto Guimarães para o programa Roda Viva, da TV Cultura, em 10/11/1986. Disponível em: https://rodaviva.fapesp.br/materia_busca/359/octavio\%20guimar\%E3es\%20pinto/entrevistados/octavi

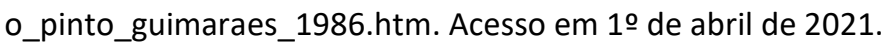


Dossiê | "Revolução com espírito empresarial": a criação do Clube dos 13 e a modernização do futebol na Folha de S. Paulo (GIGLIO, Sérgio Settani; SANTOS, João Manuel Casquinha Malaia)

como um dos pontos de inflexão importante do futebol brasileiro como sendo representativo da ideia de modernização que ganhou força no cenário esportivo nacional. Logo, a condição binária colocava de um lado a CBF como sendo o atraso e o tradicional enquanto o Clube dos 13 representava o novo e o moderno (HELAL, 1997). Não podemos perder de vista, ao longo dos fatos analisados, o que Ouriques (1998) e Rodrigues (2007) definiram como modernização conservadora do futebol brasileiro.

Para Ouriques (1998), a lógica maniqueísta se instalava também no esporte. Desse modo, a busca pela modernidade acionava a dimensão do bem e colocava do lado oposto o tradicional, como algo velho e ultrapassado. O autor, ainda, completa: “A modernidade esportiva, como todas as demais modernidades, é sempre boa em sua essência, e o que poderia existir de mal nela se explicaria porque o moderno não a abraçou ainda de todo [...]" (p. 73).

Pode-se entender a modernização conservadora como algo que pretende aparentemente mudar sua estrutura, mas que, no caso aqui analisado, colocou no centro do processo os dirigentes e empresários e não os clubes e os jogadores. Em outras palavras, a modernização não passa de uma reforma conservadora, não há a tão propalada revolução no centro do processo. Pelo contrário, conforme afirma Ouriques (1998, p. 134), a reforma conservadora é "[...] feita por aqueles que criaram-se nesta estrutura e só a estão adaptando aos seus mais novos interesses". Acreditamos que seja necessário estar atento aos diferentes discursos, tanto dos dirigentes quanto dos jornalistas, que tinham por finalidade validar esta modernização conservadora.

Nesse sentido, antes de avançar, é preciso ter o cuidado para não cair em certos idealismos, conforme apontaram Souza e Marchi Junior (2020), quando a ideia de modernização completa tem como modelo o futebol europeu. Nesse sentido, copiar o modelo torna-se imperativo como se isso resolvesse alguns dos dilemas do futebol brasileiro.

Embora essa ideia possa aparecer implícita em alguma fala de dirigentes ou do próprio jornal Folha de S. Paulo, o que propomos ressaltar é que no período referente ao ano de 1987 o modelo empresarial desponta como elemento da mudança, como elemento central de uma "revolução" no futebol. É óbvio que, de alguma maneira, a ideia empresarial refere-se ao que vem de fora, especialmente, da Europa, e tem força no cenário futebolístico nacional. A imprensa, especialmente a paulista e a carioca, 
Dossiê | "Revolução com espírito empresarial": a criação do Clube dos 13 e a modernização do futebol na Folha de S. Paulo (GIGLIO, Sérgio Settani; SANTOS, João Manuel Casquinha Malaia)

também aceitou esse discurso da defasagem do futebol brasileiro em relação ao futebol europeu (PRONI, 2000).

É, portanto, nessa linha que queremos construir os argumentos. A modernização conservadora passava pelo modelo empresarial de gestão. E, tanto os clubes quanto a Folha, aceitaram que era preciso dar esse passo para modificar a estrutura do futebol nacional. Diante desse quadro era, portanto, necessário “[...] modernizar a estrutura da organização do futebol nacional nas últimas décadas, tendo como modelo as ligas europeias de futebol" (RODRIGUES, 2007, p. 128). A criação do Clube dos 13 inicia um processo de mudanças que envolvem a legislação e a administração do futebol no país, passando pela Lei Zico e culminando com a promulgação da Lei Pelé que tem como marco o fim da lei do passe (RODRIGUES, 2007).

Ao percorrer essa história que culminou com a formação do Clube dos 13 não é somente sobre os aspectos dados que faremos as análises. O seu surgimento é fruto de uma sequência de ações, vindas de diferentes frentes, que teve como resultado a formação de uma entidade que deveria preservar e representar os interesses comerciais dos clubes que passariam a ter receitas com os direitos de transmissão (PRONI, 2020). Além desses dados, também nos interessam os aspectos ocultos de uma disputa pelo controle do poder do futebol brasileiro que envolvem a CBF, o Clube dos 13 e muitos dirigentes.

Para tentar compreender este processo a partir da perspectiva apresentada, optamos por trabalhar com o jornal Folha de S. Paulo, por ser um dos mais importantes periódicos do Brasil. A opção por acompanhar o noticiário da Folha, no entanto, não se deve apenas a este motivo. A Folha implementou, entre os anos de 1984 e 1987 (ano em que foi disputada a Copa União), um novo projeto editorial, o "Projeto Folha", cujo objetivo era colocar o jornal dentro de dinâmicas mais eficientes de mercado (SILVA, 1988).

Neste sentido, buscamos observar a maneira como os discursos em favor de uma gestão inovadora e empresarial do futebol estão dentro de todo um contexto de reformulação do próprio jornal. Este procedimento nos possibilita seguir a sugestão de 
Dossiê | "Revolução com espírito empresarial": a criação do Clube dos 13 e a modernização do futebol na Folha de S. Paulo (GIGLIO, Sérgio Settani; SANTOS, João Manuel Casquinha Malaia)

Luca (2008) de tratar os periódicos ao mesmo tempo como fonte e objeto ${ }^{6}$, algo bastante difícil, mas que procuraremos dar conta na medida em que trouxermos para análise artigos de opinião e editoriais deste jornal. As reportagens fornecem o fio narrativo do período. A ideia é que possamos compreender este material da Folha como mais uma camada de discursos legitimadores de processos de reformulação do futebol brasileiro. Ao adotar esse discurso, o jornal acaba legitimando ao mesmo tempo, tanto as mudanças no futebol brasileiro, quanto seu próprio novo projeto editorial.

Um ponto a chamar a atenção é que falamos de um universo masculino. Não há uma única mulher que apareça na trama referente ao final do campeonato brasileiro de 1986 até o início do campeonato de 1987. Esse universo masculino tampouco pode ser lido de modo exclusivo por parte do futebol, mas também pelo jornal Folha de S. Paulo consultado como fonte para esse texto. Das reportagens jornalísticas analisadas apenas uma foi assinada por uma mulher. O quadro de políticos que aparecerão ao longo desse caso é exclusivamente ocupado por homens.

\section{O monopólio do futebol}

Para entendermos os rumos que o futebol nacional teve em 1987 é preciso recuar um pouco no tempo para entender que tipo de disputas estavam postas. Os argumentos para a formação do Clube dos 13 e de um campeonato à parte eram de natureza econômica: incapacidade financeira da CBF de arcar com os custos da competição; imprimir estratégias de gestão empresarial; produzir um espetáculo mais atraente com jogos entre equipes mais famosas e de maior torcida; conseguir melhor contratos de marketing e de direitos televisivos; e vender mais ingressos. Por serem desta natureza, torna-se necessário compreender alguns princípios básicos do funcionamento econômico do esporte coletivo de entretenimento, bem como um pouco da história econômica deste fenômeno no Brasil.

É importante que se dialogar com algumas teorias econômicas dos esportes de entretenimento. Desta forma, poderemos entender melhor as forças que atuam neste

\footnotetext{
${ }^{6}$ Utilizamos para além da Folha de S. Paulo, as entrevistas de Octávio Guimarães Pinto e Nabi Abi Chedid realizadas pelo programa Roda Viva como fontes e objeto de análise desse artigo; e uma circular oficial da FIFA de 1983.
} 
Dossiê | "Revolução com espírito empresarial": a criação do Clube dos 13 e a modernização do futebol na Folha de S. Paulo (GIGLIO, Sérgio Settani; SANTOS, João Manuel Casquinha Malaia)

processo de formação de um grupo de clubes que procura organizar a competição a despeito da confederação que tinha a prerrogativa, inclusive por parte do governo, de organizar os campeonatos nacionais. O funcionamento econômico do esporte no capitalismo difere em algumas questões de outras unidades produtoras ${ }^{7}$.

Desde os anos 1960, economistas, principalmente nos Estados Unidos, passaram a se debruçar sobre esta questão visando compreender de que maneira o esporte de entretenimento poderia ser mais lucrativo. Uma das questões fundamentais de diferenciação é que, ao contrário dos demais mercados, no esporte apenas uma unidade produtora (pensemos em um clube, por exemplo) não é capaz de produzir sozinha o seu produto, um jogo. Esta unidade produtora precisa se juntar a outra unidade produtora (outro clube) para assim poderem produzir um jogo comercializável.

No entanto, apenas duas unidades produtoras realizando sempre o mesmo jogo, uma contra a outra, acabaria tornando o produto, de certa forma, repetitivo. Apesar de cada jogo ser diferente do outro, a repetição de jogos entre dois clubes torna o produto desinteressante. Por este motivo, conjuntos de unidades produtoras se reúnem no que comumente se chamou de "liga" para organizar campeonatos com jogos variados entre diversas unidades produtoras diferentes. E essas ligas se fecham e procuram monopolizar seus mercados, procurando se legitimar como a principal produtora de espetáculos de uma determinada modalidade. São estas ligas as que reúnem as principais unidades produtoras de uma cidade, de um estado, de um país, de um continente ou do mundo.

Neste momento, pensando no futebol, uma outra questão se reúne com esta característica econômica, que é justamente o problema de como obter essa legitimidade entre o público. Esta legitimidade, no futebol, está também ligada a toda uma estrutura geopolítica do esporte, comandada internacionalmente por uma "liga" internacional, a Federação Internacional de Futebol (FIFA) ${ }^{8}$. A FIFA é o órgão mundial ao qual federações nacionais de futebol se filiam para terem a legitimidade do órgão máximo internacional. Essas federações nacionais (que são legitimadas pelos Estados nacionais como representantes da modalidade em seus países) são por sua vez

\footnotetext{
7 Para maiores discussões sobre a economia do esporte Cf. Andreff e Szymanski (2007). Para pensar de maneira mais específica discussões a respeito da economia do futebol Cf. Goddard (2007).

8 Para saber mais das relações da FIFA na geopolítica mundial e seu papel na organização do futebol. Cf: Giulianotti (1999), Forster e Pope (2004) e Giglio (2018).
} 
Dossiê | "Revolução com espírito empresarial": a criação do Clube dos 13 e a modernização do futebol na Folha de S. Paulo (GIGLIO, Sérgio Settani; SANTOS, João Manuel Casquinha Malaia)

formadas por federações regionais dos países, ao qual são filiados clubes daquela região, ou diretamente pelos clubes do país. Esta configuração permite a organização de um futebol "oficial", avalizado por um órgão internacional, que compõem torneios regionais, nacionais e internacionais, todos dentro desta estrutura. Neste processo de legitimação, há a participação decisiva dos meios de comunicação.

Desta forma, podemos perceber que as estruturas formativas deste "futebol oficial" não dependem apenas de fatores econômicos. Uma vez que os Estados nacionais precisam oficializar suas federações nacionais junto à FIFA, essas federações precisam fazer parte de todo um arranjo político com governos, fato que muitas vezes fazem com que personagens do futebol adentrem as esferas oficiais do Estado, seja por meio de candidaturas a cargos eletivos, seja por indicação de pessoas ligadas ao futebol por membros do governo para ocupar cargos públicos. Some-se a isso o fato de a FIFA só aceitar filiar uma federação por país. Este elemento faz com que muitas vezes, ao longo da história, grupos que divergiam na organização do futebol em seus países ou regiões lutassem pela legitimidade frente aos seus governos nacionais e à FIFA.

No futebol brasileiro, estas lutas por legitimidade permearam as décadas de 1910, 1920 e 1930, por diversas razões: seja pela disputa pelo monopólio do mercado, pela tentativa de afastar determinados clubes das ligas ou ainda pelo monopólio da regulamentação do futebol. Na década de 1910, são famosas as disputas pelo monopólio da organização do mercado do futebol nas cidades do Rio de Janeiro e de São Paulo, as que tinham o maior desenvolvimento esportivo do país. Na década de 1920, mais precisamente em 1924, é conhecida também a história da fundação da Associação Metropolitana de Esportes Athleticos (AMEA), no Rio de Janeiro. Foi uma liga organizada por América, Botafogo, Flamengo e Fluminense com o objetivo de barrar os jogadores negros e brancos pobres que levaram o Vasco da Gama a vencer no ano anterior o título de campeão da Liga Metropolitana de Desportes Terrestres (LMDT), a liga que reunia até então os maiores e mais importantes clubes da cidade. Durante aquele ano, o Rio de Janeiro teve dois campeonatos e dois campeões diferentes da cidade.

Na década de 1930, a questão que levou ao rompimento das principais ligas e a formação de novas ligas foi a institucionalização do profissionalismo de jogadores, em 1933. A FIFA aceitava o profissionalismo, mas impedia que profissionais jogassem contra 
Dossiê | "Revolução com espírito empresarial": a criação do Clube dos 13 e a modernização do futebol na Folha de S. Paulo (GIGLIO, Sérgio Settani; SANTOS, João Manuel Casquinha Malaia)

amadores. Portanto, as ligas nacionais deveriam adotar apenas um sistema de atletas: amadores ou profissionais. A questão se tornou complexa, pois apesar de o governo ter autorizado o trabalho legal de jogadores de futebol, a Confederação Brasileira de Desportos (CBD) não adotou o profissionalismo de seus atletas, proibindo clubes que contassem com jogadores profissionais de atuar em campeonatos regulamentados por ela e que jogadores profissionais fossem impedidos de jogar pela seleção brasileira. Mais uma vez, Rio de Janeiro e São Paulo foram palco de campeonatos diferentes, um com clubes que contratavam jogadores profissionais e outro com clubes que contavam apenas com atletas supostamente amadores (SANTOS, 2012).

Esta questão se mostra presente inclusive em disputas atuais pela memória dos clubes e do futebol brasileiro. Quando visitamos páginas da Wikipédia, das federações e dos clubes para contabilizar o número de campeonatos disputados e o número de títulos dos clubes ${ }^{9}$, vemos situações curiosas. Como exemplo, ao consultarmos a página oficial da Federação Paulista de Futebol, entre 1913 e 1917, são citados dois campeões em cada ano: um da Liga Paulista de Futebol e outro da Associação Paulista de Esportes Atléticos. Esta situação se repete nos anos 1935 e 1936. Apenas para pensarmos nos maiores clubes de São Paulo, nesse período foram conquistados dois títulos pelo Corinthians, dois pela Portuguesa de Desportos, um pelo Palestra Itália e um pelo Santos e que estão contabilizados em seus panteões de conquistas, independente do campeonato disputado ${ }^{10}$.

O que procuramos mostrar com esta breve reflexão é que as disputas pelo monopólio do futebol produzido para grandes audiências não é algo novo na história, nem no futebol brasileiro e nem no futebol mundial. Diferentes questões, em distintos contextos levaram a cisões que envolviam justamente tentativas de conquista ou manutenção do monopólio da organização de um dos fenômenos mais importantes do entretenimento urbano nas principais cidades do Brasil e do mundo. A iniciativa por parte de dirigentes de alguns dos maiores clubes de futebol do Brasil na criação do Clube dos 13 , indica que a tentativa de organizar um novo campeonato sem as diretrizes da Confederação Brasileira de Futebol e a de gerir o futebol a partir de uma nova lógica monopolista foi mais uma etapa deste longo processo histórico.

\footnotetext{
${ }^{9} \mathrm{Cf}:$ https://futebolpaulista.com.br/Clubes/TodosCampeoes.aspx. Acesso em 5 Abr. 2021

${ }^{10}$ Cf.: https://futebolpaulista.com.br/Clubes/TodosCampeoes.aspx. Acesso em 6 Abr. 2021.
} 
Dossiê | "Revolução com espírito empresarial": a criação do Clube dos 13 e a modernização do futebol na Folha de S. Paulo (GIGLIO, Sérgio Settani; SANTOS, João Manuel Casquinha Malaia)

\section{Os empresários}

No início de 1987, o jornalista Aroldo Chiorino trazia em sua coluna na Folha de São Paulo, o tema do "Futebol-Empresa" marcado no título do seu artigo. Tomava como argumento central uma fala do “jornalista-empresário Luciano do Valle e agora técnico da seleção brasileira de seniors", ao jornal Popular da Tarde, que defendia que o futebol brasileiro deveria ser gerido em termos empresariais. A justificativa era de que pessoas como Nabi Abi Chedid (vice-presidente da CBF) e José Maria Marin (presidente da Federação Paulista de Futebol) não acrescentavam nada ao futebol. Aproveitando os argumentos de Luciano do Valle, Chiorino apontava o que deveria ser feito no futebol brasileiro:

Entendemos que o futebol precisa realmente ser dirigido profissionalmente e a maneira a ser aplicada é um assunto que deve ser estudado por quem de direito. A verdade é que pessoas ou empresas envolvidas com o futebol, direta ou indiretamente, pensam como profissionais ou comerciantes, defendendo, com justiça, seus interesses. Por que, nas condições atuais, os clubes, por exemplo, têm que ser menos profissionais do que os outros? Neste aspecto, a legislação esportiva brasileira está superada. Precisaria ser revista, para que o futebol fosse dirigido como empresa, como acontece em alguns países da Europa. Nos clubes, ninguém acaba sendo responsável pelas dívidas, afinal o dinheiro não é dos dirigentes e eles, na maioria dos casos, acabam cometendo verdadeiros desastres em administrar as finanças das agremiações. ${ }^{11}$

O uso por parte de Chiorino do ponto de vista apresentado por Luciano do Valle apresentava-se como uma forma de validar, por meio de uma chancela, o detalhamento de seu argumento. A posição de Luciano do Valle refletia, por certo, seu lugar na cena esportiva brasileira. Ocupava o lugar que já havia sido de grandes jornalistas brasileiros que, para além do seu trabalho, se destacaram por promover o esporte e o faziam isso tendo seus veículos de imprensa como seu grande aliado. Um exemplo disso, foi a atuação de Mário Filho à frente do Jornal dos Sports, responsável por promover e organizar a Copa Rio, uma espécie de torneio internacional de clubes disputado no Maracanã nos anos de 1951 e 1952. As críticas de Luciano do Valle aos dirigentes brasileiros eram certeiras, mas sua justificativa talvez refletisse o cenário ao qual

\footnotetext{
${ }^{11}$ CHIORINO, Aroldo. Futebol-empresa. Folha de S. Paulo, 18 de janeiro de 1987, p. A31.
} 
Dossiê | "Revolução com espírito empresarial": a criação do Clube dos 13 e a modernização do futebol na Folha de S. Paulo (GIGLIO, Sérgio Settani; SANTOS, João Manuel Casquinha Malaia)

também circulava - o empresariado - como se fosse uma retribuição aos patrocinadores de seus programas televisivos. Sua defesa da classe empresarial era uma dívida adquirida com a classe que apoiava o esporte. As notícias seguintes indicavam que os empresários chegariam de vez ao futebol. ${ }^{12}$

A presença das marcas nas camisas era algo ainda em expansão no Brasil em 1987. A FIFA era a responsável por estabelecer as regras deste tipo de publicidade. A autorização da FIFA para tal procedimento foi definida no dia 8 de agosto de 1982, sendo regulamentada por meio da circular número 312 de 29 de março de $1983^{13}$. A CBF autorizou a publicidade nos uniformes dos clubes brasileiros também em 1983, mas havia segundo a reportagem algumas restrições:

Pela atual regulamentação, seguida por todos os países filiados à Fifa, o espaço a ser comercializado é limitado. Na parte frontal não pode exceder $25 \mathrm{~cm}$ de largura por $10 \mathrm{~cm}$ de altura, e deve estar colocado em nível inferior ao do distintivo da equipe. Nas costas, o máximo permitido é $55 \mathrm{~cm}$ de largura por $15 \mathrm{~cm}$ de altura. Quanto à marca do fabricante do material esportivo, deve ocupar um espaço não superior a 16,2 cm. A Fifa proíbe a publicidade de cigarros, bebidas alcoólicas e jogos de azar. Também é proibido comercializar espaço nas camisas de equipes formadas por jogadores com idade menor de cartoze anos. No Brasil, o Conselho Nacional de Desportos (CND) vetou, em 1 o de abril de 1984, o uso de frases, expressões ou referências políticas, religiosas e raciais ${ }^{14}$.

Embora a regulamentação já estivesse em vigor há pelo menos três anos, ainda existiam clubes que não possuíam patrocínio em suas camisas. O que havia naquele momento, era um investimento de patrocínio com motivação da paixão clubística e, em menor número, um investimento meramente empresarial por entender que determinado clube poderia visibilizar a marca de uma empresa em um nicho específico. ${ }^{15}$

As propagandas nas camisas eram apenas um dos sintomas mais visíveis que a estrutura do futebol passava a evidenciar. As marcas haviam chegado para potencializar

\footnotetext{
12 Aqui é preciso realizar uma pequena digressão. A presença dos empresários não era novidade no cenário futebolístico nacional. Participaram ativamente do "Planejamento México" garantindo um investimento financeiro - cerca 1 milhão de Cruzeiros - para que essa preparação lograsse êxito (ROCHA, 2019).

${ }^{13}$ A circular foi assinada pelo Secretário-Geral da FIFA, Joseph S. Blatter, em 29 de março de 1983. Circular No 312, Publicity on sports equipment. FIFA documents.

${ }^{14}$ Publicidade já tem cinco anos. Folha de S. Paulo, 4 de fevereiro de 1987, p. A18.

${ }^{15}$ Empresários apaixonados garantem patrocínio aos clubes Folha de S. Paulo, 4 de fevereiro de 1987, p. A18.
} 
Dossiê | "Revolução com espírito empresarial": a criação do Clube dos 13 e a modernização do futebol na Folha de S. Paulo (GIGLIO, Sérgio Settani; SANTOS, João Manuel Casquinha Malaia)

a transformação do futebol enquanto negócio. Mas elas não estavam sozinhas. Havia também outro ingrediente que passava a compor o cenário, ao menos, do futebol brasileiro de forma mais evidente: a presença dos intermediários, que mais tarde seriam oficializados como agentes do futebol. ${ }^{16}$ Isso colocava em primeiro plano a presença dos empresários. Muitas vezes, esses agentes eram vistos como um "mal necessário", ou seja, sem eles os jogadores não teriam como circular dentro do mercado futebolístico porque estariam focados em jogar. Mas o problema no Brasil era que a legislação proibia a presença de intermediários na compra e venda de jogadores. ${ }^{17}$

A dimensão da mudança pela qual o futebol brasileiro deveria passar não estava apenas vinculada a uma maior participação do empresariado, mas também de uma mudança dos clubes transformando-se, de fato, em uma empresa. Um dos clubes que tratou de ser um representante desta nova mentalidade foi o São Paulo FC. O longo trabalho de reformulação do clube havia começado no início dos anos 1980 e essa competência se materializava naquela ocasião por meio da conquista do Campeonato Brasileiro de 1986, credenciando assim o clube para voos maiores ${ }^{18}$.

A conquista mostrava, ainda, que o futebol precisava de uma estrutura capaz de controlar o treinamento, daí a necessidade em investir em um Centro de Treinamento que pudesse tratar e dar as condições necessárias aos jogadores. O presidente Carlos Aidar era o responsável por implementar uma "nova filosofia de administração, baseada quase numa linha empresarial". Para isso, era preciso garantir os recursos financeiros que viabilizassem esse ciclo se fechar:

O dinheiro vem de diversas fontes: publicidade estática no estádio ( $\mathrm{C} z \$ 500$ mil mensais), aluguel de campo, publicidade nas camisas e de um contrato com a Brahma, que este ano investirá Cz\$30 milhões no Centro de Treinamento, em troca da venda exclusiva no Morumbi. Atualmente, o São Paulo tem cerca de 25 mil sócios. ${ }^{19}$

\footnotetext{
${ }^{16}$ Cf: Tonini e Giglio (2019).

${ }^{17}$ ASSUMPÇÃO, Gustavo. Empresários driblam lei para dominar mercado do futebol. Folha de S. Paulo, 16 de fevereiro de 1987, p. A20.

${ }^{18} \mathrm{O}$ "Projeto Tóquio" começou a ser delineado em 1987. Nesse sentido, ganhar a Libertadores da América e o Mundial de Clubes seria possível por meio de um "futebol administrado com competência". E o São Paulo, de certo modo, transformou-se em modelo de gestão a ser seguido. A conquistado de duas Libertadores na década de 1990 e a concretização do Projeto Tóquio, com as vitórias nos mundiais daquele período, eram a prova do sucesso desta receita e marcaram novos parâmetros de gestão e de ambição em termos de conquistas.

${ }^{19}$ Clube adota administração nos moldes de uma empresa. Folha de S. Paulo, 26 de fevereiro de 1987, p. A22.
} 
Dossiê | "Revolução com espírito empresarial": a criação do Clube dos 13 e a modernização do futebol na Folha de S. Paulo (GIGLIO, Sérgio Settani; SANTOS, João Manuel Casquinha Malaia)

Administrar o futebol com competência seria possível somente por meio de uma mudança importante. A antiga cartolagem precisaria aderir a um modelo de gestão empresarial de modo a resgatar a essência do futebol brasileiro. Para Rocha (2013, p. 109), a Revista Placar defendia uma reforma modernizadora do futebol e "o São Paulo Futebol Clube reunia todos os atributos necessários para encarnar o modelo defendido pela revista, porém seria necessário um trabalho árduo para garantir a consolidação dessa proposta".

O sucesso financeiro do São Paulo Futebol Clube não era compartilhado pela CBF. Ao final do Campeonato Brasileiro a CBF registrava um déficit de Cz\$ 4,5 milhões justificados pelo presidente Octávio Pinto Guimarães pelos gastos que envolveram pagamentos de passagens e ajuda de custo. ${ }^{20}$

\section{7: o ano de mudanças no futebol brasileiro ou a sua desmoralização?}

Até chegarmos a 1988 ainda vai haver mais coisa, tem que haver. É uma revolução. Não se faz uma revolução impunemente e nem de graça, tem que haver convulsão, tem que haver tumulto. Agora ninguém teve a coragem de fazer o que nós vamos fazer, de dividir o futebol em três divisões - que atenderá o que a grande imprensa sempre solicitou (Octávio Guimarães Pinto, 1986). ${ }^{21}$

O ano de 1987 se inicia com a continuidade da segunda fase do Campeonato Brasileiro de 1986. A tabela do campeonato inteiro não era divulgada na íntegra sendo, portanto, divulgada aos poucos ${ }^{22}$. Tal fato poderia apenas representar uma desorganização e com o desejo de haver uma definição de um calendário nacional para o futebol brasileiro. Mas, no entanto, a suposta desorganização favorecia os ajustes que incluíam ou excluíam clubes por diferentes motivos. Nesse sentido, a Portuguesa havia

\footnotetext{
${ }^{20}$ CBF tem prejuízo de Cz\$ 4,5 milhões. Folha de S. Paulo, 10 de março de 1987, p. A24.

${ }^{21}$ Entrevista de Octávio Pinto Guimarães para o programa Roda Viva, da TV Cultura, em 10/11/1986. Disponível em: https://rodaviva.fapesp.br/materia_busca/359/octavio\%20guimar\%E3es\%20pinto/entrevistados/octavi o_pinto_guimaraes_1986.htm. Acesso em 10 de abril de 2021.

${ }^{22}$ CBF divulga tabela sem clube paranaense. Folha de S. Paulo, 6 de janeiro de 1987, p. A19; Assembléia de clubes confirma o boicote ao Coritiba. Folha de S. Paulo, 7 de janeiro de 1987, p. A20.
} 
Dossiê | "Revolução com espírito empresarial": a criação do Clube dos 13 e a modernização do futebol na Folha de S. Paulo (GIGLIO, Sérgio Settani; SANTOS, João Manuel Casquinha Malaia)

sido retirada em outubro de 1986 do campeonato de 1987 sob a justificativa de ter depositado a taxa da renda destinada à CBF em juízo. Tal fato escondia outro:

Atrás dessa manobra, havia o interesse do Vasco da Gama que não conseguiu classificar-se entre os 28 times que passariam a disputar a 1 1 a Divisão em 87. Com o problema na Justiça Desportiva e depois na Comum, a Portuguesa conseguiu sua reintegração e os clubes junto com a CBF, decidiram aumentar as vagas para 32. Entraram Joinville, Vasco, Santa Cruz, Náutico e Sobradinho. ${ }^{23}$

A essa lista somavam-se Vitória, Ponte Preta, Central de Caruaru, Sport Recife, Nacional (AM), Comercial (MS) e Operário (MS). O Coritiba e o Botafogo haviam conseguido na Justiça o direito de participar do campeonato de 1987 . O advogado especializado na Justiça Esportiva era Valed Perry. Por ser um dos poucos especialistas do país na temática ele figurava de maneira recorrente nos pedidos judiciais movidos pelos clubes. O campeonato que teria início no segundo semestre de 1987 estava previsto para ter 24 clubes, mas diante das liminares já estava com 28 clubes e a lista poderia aumentar caso todos os clubes que pleiteassem a vaga conseguissem autorização para figurar na primeira divisão do campeonato. ${ }^{24}$

O editorial da Folha do dia 12 de junho de 1987 trazia uma crítica ao futebol brasileiro e entendia que aquilo era basicamente o seu modus operandi. A síntese do argumento dava conta de mostrar a complexidade das relações estabelecidas pelos dirigentes esportivos:

$\mathrm{Na}$ realidade, é difícil distinguir entre esta crise e as precedentes; e os responsáveis são os mesmos de longa data. Há clubes desclassificados que querem entrar no próximo campeonato nacional através da Justiça, Comum ou Desportiva; há federações interessadas em manter o máximo de equipes jogando nas primeiras divisões estaduais; e há o Conselho Nacional de Desportos (CND) e a Confederação Brasileira de Futebol (CBF). ${ }^{25}$

Após a reunião, Manoel Tubino, presidente do CND entendia que as federações e a CBF deveriam desistir de acionar a Justiça Comum. Esse ponto era compartilhado por Nabi Abi Chedid que era favorável à suspensão de todos os recursos que estavam

\footnotetext{
23 Juiz manda CBF incluir Coritiba na Primeira Divisão. Folha de S. Paulo, 10 de junho de 1987, p. A21.

${ }^{24}$ Mais 9 clubes ameaçam virar a mesa no Brasileiro 87. Folha de S. Paulo, 11 de junho de 1987, p. A22.

${ }^{25}$ A velha crise do futebol. Folha de S. Paulo, 12 de junho de 1987, p. A2.
} 
Dossiê | "Revolução com espírito empresarial": a criação do Clube dos 13 e a modernização do futebol na Folha de S. Paulo (GIGLIO, Sérgio Settani; SANTOS, João Manuel Casquinha Malaia)

na Justiça. A visão de Tubino era que a CBF deveria ser responsabilizada pelos problemas administrativos. Já se falava em campeonato da bagunça e virada de mesa. ${ }^{26}$

O Campeonato Brasileiro de 1987 tinha previsão de início no final de agosto, mas os problemas que se avolumavam nos bastidores do futebol brasileiro indicavam que algo não sairia como o planejado. Afinal, a previsão do ano anterior era que o campeonato teria 28 clubes, mas Nabi Abi Chedid já pensava em ter uma disputa com 44 clubes. ${ }^{27} \mathrm{O}$ presidente Octávio Pinto Guimarães era favorável à manutenção de 28 clubes na primeira divisão e considerava interessante a proposta dos presidentes de federações para realizar a primeira fase de modo regional. Essa medida seria uma forma de organizar o campeonato diante da inclusão de mais clubes e viabilizá-la economicamente. $^{28}$

A alternativa ao modelo regionalizado também foi apresentada pelo presidente da CBF. Em crise financeira, a CBF não tinha dinheiro suficiente para organizar o campeonato brasileiro e estava à espera de um patrocínio de Cz\$100 milhões para viabilizar o campeonato ${ }^{29}$. Porém, se esse patrocínio não se concretizasse a CBF poderia propor "aos clubes um campeonato autofinanciável, ou seja, eles próprios teriam de arcar com as despesas das viagens necessárias para a realização dos jogos" ${ }^{30}$

O mês de julho iniciava-se com a CBF dizendo que não teria verba suficiente para organizar o campeonato brasileiro a não ser que os clubes ficassem responsáveis pelos custos de hospedagem e transporte. ${ }^{31}$ Como tal posicionamento não era novidade, 0 que saltava nas páginas da Folha era o bilhete de José Sarney, presidente da República, enviado para o presidente da CBF, Octávio Pinto Magalhães, em que continha a mensagem: "obséquio de examinar a possibilidade de atender o nosso popular Botafogo".

\footnotetext{
${ }^{26}$ Rebaixados entram e Tubino fecha os olhos. Folha de S. Paulo, 12 de junho de 1987, p. A22.

27 Político, Nabi já pensa em convidar os descontentes para o Brasileiro 87. Folha de S. Paulo, 16 de junho de 1987, p. A24.

28 Octavio Pinto já admite a regionalização do Brasileiro. Folha de S. Paulo, 23 de junho de 1987, p. A20.

${ }^{29}$ No mês de novembro de 1987, a CBF anunciava um déficit nas contas da entidade justificadas pela falta de receitas. Déficit da entidade pode chegar a $\mathrm{Cz} \$ 100 \mathrm{mi}$, afirma dirigente. Folha de S. Paulo, 4 de novembro de 1987, p. A22.

${ }^{30}$ Octávio diz que CBF está 'quebrada'; Brasileiro 87 pode ser regionalizado. Folha de S. Paulo, 8 de julho de 1987, p. A18; Octávio alega falta de dinheiro para 'enxugar' o Campeonato Brasileiro. Folha de S. Paulo, 9 de julho de 1987, p. A22.

${ }^{31}$ CBF admite que clubes banquem o Brasileiro. Folha de S. Paulo, 10 de julho de 1987, p. A20.
} 
Dossiê | "Revolução com espírito empresarial": a criação do Clube dos 13 e a modernização do futebol na Folha de S. Paulo (GIGLIO, Sérgio Settani; SANTOS, João Manuel Casquinha Malaia)

Sarney havia recebido o deputado federal João Cunha (PMDB) e Édson Damasceno, presidente do conselho deliberativo do Botafogo de Ribeirão Preto (clube que sequer foi um dos 80 participantes da primeira divisão de 1986). João Cunha moviase com a intenção de incluir o Botafogo na primeira divisão enquanto Damasceno defendia-se dizendo que a intenção da reunião havia sido para pedir "verbas para a conclusão do poliesportivo que estamos construindo e outras obras que precisamos realizar". O presidente do Botafogo, Oswaldo Silva, não havia gostado do posicionamento de Cunha e reforçava que não ia "abraçar a bandeira do Cunha, porque o esporte é contra a política e eu não quero brigar com outros políticos de Ribeirão". ${ }^{32}$

Embora Damasceno tenha apresentado essa pauta, também havia uma mensagem dúbia, especialmente no sentido de que toda ajuda poderia ser bem-vinda. Assim Damasceno analisava a situação e desconstruía o argumento de que o futebol e política eram antagônicos: "Não devemos ser ingênuos e pensar que não existe política no futebol. Existe política em todos os lugares do Brasil e o Cunha está nos ajudando, e eu pergunto se não é por razões políticas que estamos fora do Brasileiro". ${ }^{33}$ Quase como um detalhe do bilhete há um destaque para as pessoas que compuseram a comitiva e lá estavam os "micro-empresários de nossa região". No dia seguinte, Oswaldo Silva, mudava o seu discurso e aceitava o apoio do presidente da República, conforme telex enviado ao José Sarney:

Exmo Sr. Dr. José Sarney

Presidente da República Federativa do Brasil

Senhor Presidente,

Lamentando o noticiário de parte da imprensa, afirmando que estaria rejeitando o apoio de V. Exa., no caso de reivindicações levadas a V. Exa., desejo expressamente desmentir o que está publicado. Como presidente do Botafogo Futebol Clube, solicitei ao amigo deputado João Cunha, que nos levasse a V. Exa, para tratarmos da questão grave do recolhimento previdenciário por parte dos clubes de futebol e, na audiência concedida por V. Exa, para tal fim, queremos testemunhar que pedimos a $\mathrm{V}$. Exa, que nos ajudasse a abrir as portas da CBF para o fim de convencermos o órgão da importância de colocarmos nosso time no Campeonato Nacional. Queremos destacar a forma cortês e amiga com que nos recebeu juntamente com a comitiva de micro-empresários de nossa região. E sabemos que o gesto de V. Exa., encaminhando-nos ao presidente da CBF decorreu da simpatia e apreço, expressando um gesto de cortesia, sem nenhuma

\footnotetext{
32 Botafogo recusa interferência de Sarney no campeonato. Folha de S. Paulo, 10 de julho de 1987, p. A20.

${ }^{33}$ Idem.
} 
Dossiê | "Revolução com espírito empresarial": a criação do Clube dos 13 e a modernização do futebol na Folha de S. Paulo (GIGLIO, Sérgio Settani; SANTOS, João Manuel Casquinha Malaia)

conotação política e sem demérito ou prejuízo para quem quer que seja. Destacamos nossa admiração por V. Exa., Senhor Presidente, mantendo-nos agracidos pela honra com que nos distinguiu. Cortesmente, Oswaldo Silva. ${ }^{34}$

O efeito que as ações vindas de todos os lados na busca por uma vaga no campeonato brasileiro bem como a falta de posicionamento da CBF em garantir a realização do torneio facilitou a aproximação de dirigentes que andavam descontentes com a entidade responsável por organizar o futebol no Brasil. Desse modo, era criada a União dos Grandes Clubes do Futebol Brasileiro, ou apenas Clube dos 13, formada por 13 clubes que visava estabelecer jogos apenas aos finais de semana a partir de 1988, regionalizar as divisões $\mathrm{C}$ e abaixo para diminuir as despesas, consulta prévia aos clubes para a convocação dos atletas para a seleção brasileira e a elaboração de um calendário nacional a partir de $1988 .^{35}$

Embora o argumento principal para a criação do Clube dos 13 fosse o acúmulo de discussões que tinham o ano de 1987 como seu auge, o presidente do São Paulo, Carlos Aidar resumia o que estava em jogo: "Nós queremos o poder". Ressaltava ainda que "Decidimos criar a União e formular as propostas porque a Confederação Brasileira de Futebol não definiu como vai ser o próximo campeonato. E se formos convidados para participar dele, não aceitaremos". Tal ação colocava pressão sobre a CBF e que fazia Octávio Pinto Guimarães buscar apoio jurídico para saber se essa iniciativa - a de criação de um campeonato paralelo ao Brasileiro - era legal. ${ }^{36}$

Aidar assumia a presidência do Clube dos 13 e tinha Márcio Braga, presidente do Flamengo, como vice-presidente. Apesar de Octávio Pinto ainda esperar por uma resposta jurídica da CBF sobre a proposta da criação da Copa União, a sua aprovação resolveria, a princípio, o problema da falta de verba para a organização do campeonato. Porém, o que estava no centro do debate era a disputa pelo poder do controle do futebol brasileiro. Segundo Márcio Braga, o presidente da CBF "não quer perder poder" e para isso acontecer ele teria apenas uma saída: "aceitar o processo revolucionário" que estava em curso no futebol brasileiro. ${ }^{37}$

\footnotetext{
34 Íntegra do telex do clube paulista ao presidente. Folha de S. Paulo, 11 de julho de 1987, p. A14.

35 União dos Grandes Clubes quer limitar poder da CBF. Folha de S. Paulo, 13 de julho de 1987, p. A19.

${ }^{36}$ Idem.

${ }^{37}$ CBF articula Campeonato Nacional com treze clubes. Folha de S. Paulo, 14 de julho de 1987, p. A14.
} 
Dossiê | "Revolução com espírito empresarial": a criação do Clube dos 13 e a modernização do futebol na Folha de S. Paulo (GIGLIO, Sérgio Settani; SANTOS, João Manuel Casquinha Malaia)

Nessa visão "revolucionária" que tinha como mote um novo futebol brasileiro, outros problemas passavam a surgir. A exclusão dos clubes Sport, Náutico e Santa Cruz já criava rupturas em algo que estava apenas em formação. O presidente do conselho deliberativo do Botafogo de Ribeirão Preto voltava a se manifestar, afinal, toda sua articulação junto ao presidente da República teria sido em vão diante da criação de um rol seleto de clubes do futebol brasileiro. Em suas palavras, Édson Damaceno apontava o movimento como uma discriminação e reforçava que "o futebol brasileiro está em decadência, falta de organização". ${ }^{38}$ Para o presidente da Portuguesa, Oswaldo Teixeira Duarte, a exclusão do clube do rol dos grandes do futebol brasileiro era um boicote promovido por Aidar porque "A Portuguesa não quis apoiar o movimento que pretendia mudar o regulamento do Campeonato Paulista, ou seja, voltar a ter o descenso de apenas dois em vez de quatro" e Teixeira completava que o posicionamento de Aidar era "uma incoerência do presidente do São Paulo, que prega a diminuição do número de clubes a nível nacional e defende o aumento a nível regional" ${ }^{39}$

Além da aresta que teria que ser aparada em relação aos clubes que ficariam de fora do seleto rol dos "grandes clubes", o efeito da criação do Clube dos 13 parecia surtir efeitos colaterais que incidiam diretamente na busca pelo poder e controle do futebol brasileiro gerando uma cisão interna na CBF. Apesar de o presidente da CBF ter sido reticente, de início, com criação da Copa União, a organização do campeonato por parte dos clubes solucionava o seu maior problema: o financeiro. Por isso, sua opinião ainda que mediada pela fala de Márcio Braga aparecia como uma boa solução. No entanto, essa opinião colidia com o pensamento do vice-presidente Nabi Abi Chedid. Em tom de ameaça Nabi dizia: "quem quiser, que pague para ver, que vai ter troco" por entender que a organização do campeonato brasileiro deveria ser da CBF e que "a entidade irá desfiliar os treze clubes, caso eles desistam de participar do Campeonato Brasileiro para organizar a Copa União". A proposta referente ao Clube dos 13 está sintetizada na tabela abaixo: 40

\footnotetext{
${ }^{38}$ Dirigente acusa União dos Treze de traição. Folha de S. Paulo, 14 de julho de 1987, p. A14.

${ }^{39}$ Nabi ameaça expulsar da CBF os treze grandes clubes. Folha de S. Paulo, 15 de julho de 1987, p. A14.

40 Idem.
} 
Dossiê | "Revolução com espírito empresarial": a criação do Clube dos 13 e a modernização do futebol na Folha de S. Paulo (GIGLIO, Sérgio Settani; SANTOS, João Manuel Casquinha Malaia)

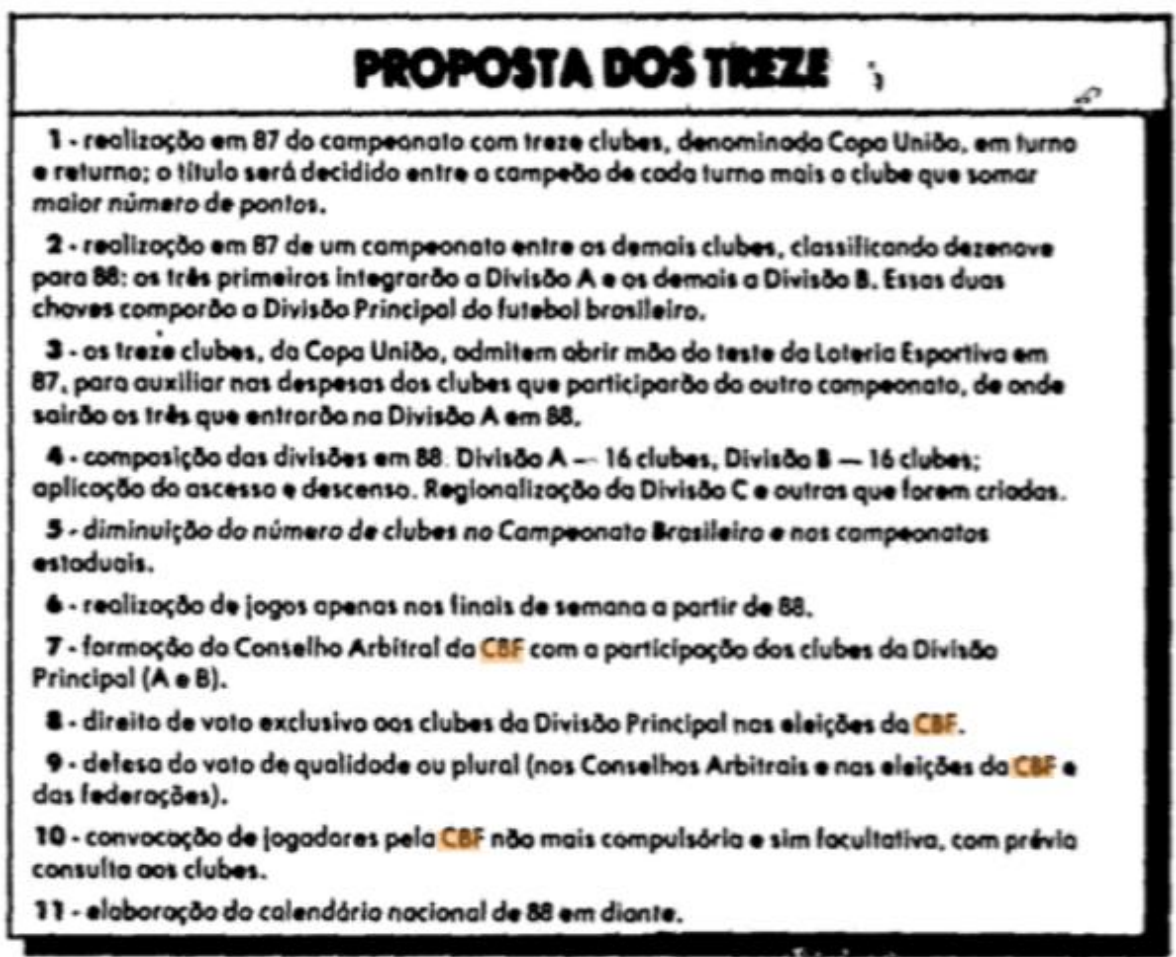

A busca pela legitimidade em organizar o futebol nacional colocava frente a frente a CBF e o recém-criado Clube dos 13. Efetivamente o embate se materializava na troca de acusações entre o vice-presidente da CBF, Nabi Abi Chedid e o presidente do Clube dos 13, Carlos Aidar. Para Nabi, os clubes que ingressassem no Clube dos 13 deveriam ser excluídos da CBF e os jogadores teriam passe livre de forma gratuita. Para Aidar, as ameaças de Nabi eram ilegais e defendia que a formação do Clube dos 13 representava uma revolução. ${ }^{41}$

Nesse jogo de interesses, o vice-presidente do Clube dos 13 e presidente do Vasco da Gama, Eurico Miranda, aceitava negociar para se chegar em 16 clubes, ${ }^{42}$ mas não aceitava pensar em um campeonato com 28 clubes como era o que estava sendo sinalizado pela CBF. O cenário da época indicava que o jogo político envolvendo as barganhas para entrar no campeonato nacional era muito mais complexo do que incluir apenas três clubes. Afinal, pela conta inicial haveria, pelo menos, o descontentamento de outros 12 clubes. Sem contar, os que não estavam nesta lista e queriam integrar o campeonato.

Os excluídos buscavam se organizar e não aceitar a imposição do Clube dos 13 sobre quem poderia fazer parte desse seleto grupo. O então presidente do Santa Cruz

\footnotetext{
${ }^{41}$ Clube dos 13 pode perder passe de seus jogadores. Folha de S. Paulo, 16 de julho de 1987, p. A20.

${ }^{42}$ Clube dos 13 já admite torneio com 16 e vai a Ulysses. Folha de S. Paulo, 17 de julho de 1987, p. A15.
} 
Dossiê | "Revolução com espírito empresarial": a criação do Clube dos 13 e a modernização do futebol na Folha de S. Paulo (GIGLIO, Sérgio Settani; SANTOS, João Manuel Casquinha Malaia)

de Recife, José Neves, aparecia como o futuro presidente da Associação Brasileira de Clubes de Futebol (ABCF) e buscava o apoio da CBF para organizar um campeonato com recursos da Loteria Esportiva. ${ }^{43}$

Uma nota assinada ${ }^{44}$ por entidades do Rio de Janeiro reforçava a pressão sobre a CBF, especialmente, quando Nabi começava a ceder para a proposta do Clubes do 13 e sinalizava que era importante haver "conciliação e consenso". Com isso, passava a defender publicamente no programa Esporte Total, da Rede Bandeirantes, que os módulos de cada divisão do futebol tivessem 16 clubes ${ }^{45} \mathrm{~A}$ nota apontava que a formação do Clube dos 13 representava a "reimplantação da ditadura futebolística pela renovação do autoritarismo político-ideológico da oligarquia elitista de treze associações esportivas". ${ }^{46}$

Antes de avançar nos fatos que mostravam, a princípio, pontos de ruptura e descontinuidades, a mudança de posicionamento da CBF, especialmente, pela figura de Nabi indicava que a conciliação e a continuidade era um caminho mais interessante para quem estava no poder. Desse modo, o editorial da Folha intitulado Rebelião no futebol apresentava algumas reflexões sobre o processo em curso:

Ainda que opere as reformas e inovações necessárias, a proposta de formação de uma nova liga dos treze filiados mais poderosos da CBF não deixa de apresentar o dado extraordinário de que os dirigentes rebelados só agora se movimentam contra um fato há muito conhecido por todos: a falência, econômica e técnica, do futebol brasileiro.

Concebido com a participação e conivência dos que hoje se batem por uma reformulação do regulamento, o campeonato nacional não consegue mais atender ao sistema de clientelismo e distribuição de favores que the deu origem e sustento durante muitos anos. Com o lucro declinante das verbas da loteria e o esvaziamento crescente dos estádios, a situação financeira da Confederação e das agremiações está mais que debilitada.

A presente ameaça de cisão aponta, sem dúvida, para avanços importantes como a redução dos gastos de viagem, o aumento da rivalidade e do interesse pelas partidas, a melhoria das condições de trabalho dos atletas -hoje dividindo suas vidas entre os jogos e as concentrações.

Embora sejam perspectivas promissoras, não se deve precipitar a euforia. Por mais ampla e progressista que pareça, a reforma que se

\footnotetext{
${ }^{43}$ Associação vai apresentar sua fórmula. Folha de S. Paulo, 17 de julho de 1987, p. A15.

${ }^{44}$ Assinavam a nota: Sindicatos dos Atletas de Futebol, Reginaldo Matias; dos Treinadores Profissionais, Flávio Costa; dos Empregados de Clubes, Federações e Confederações Esportivas e Atletas Profissionais, Carlos Alberto Santos Alves; e da Associação Brasileira de Treinadores de Futebol, Orlando Peçanha.

45 Nabi defende. Folha de S. Paulo, 19 de julho de 1987, p. A36.

${ }^{46}$ Nabi também defende o campeonato com 16 clubes. Folha de S. Paulo. 18 de julho de 1987, p. A18.
} 
Dossiê | "Revolução com espírito empresarial": a criação do Clube dos 13 e a modernização do futebol na Folha de S. Paulo (GIGLIO, Sérgio Settani; SANTOS, João Manuel Casquinha Malaia)

pretende realizar não liberta os clubes dos humores e do personalismo dos dirigentes.

Para que tenha sucesso, a renovação do futebol deve ser feita com espírito empresarial, como ocorre em outros países, em que pese a dor que isso possa causar no coração dos torcedores mais saudosos. ${ }^{47}$

Esse editorial da Folha de julho de 1987 trazia uma dimensão da crítica que até aquele momento não havia aparecido nas reportagens e até mesmo no próprio editorial. Apontava que a mudança estava sendo proposta pelos mesmos dirigentes que haviam levado o futebol brasileiro para o lugar da desorganização e endividamento. Era como se o futebol tivesse se esgotado em sua dimensão clientelista e precisava se renovar. A renovação, por sua vez, seria a oportunidade de consertar o que estava errado. O próprio editorial, no entanto, ressaltava a necessidade em conter a euforia porque a gestão ficaria nas mãos das mesmas pessoas. Em que pese o argumento ser plausível, a sua justificativa de uma mudança efetiva estava centrada na entrada de uma gestão empresarial como se fosse sinônimo de lisura e boas práticas. Qual seria a diferença dos dirigentes para os empresários? Vistos apenas como solução, não se procurava discutir o que seriam as propostas de mudanças. E, também, a defesa pelo modelo empresarial estava alinhada ao seu novo projeto editorial de jornal daquela época.

É nesse cenário que Ricardo Teixeira, então apenas apresentado como dono de uma investidora e genro do dirigente João Havelange ${ }^{48}$ que, na época era o presidente da FIFA, iniciava a sua campanha para a sucessão da presidência da CBF. Em outras palavras, Teixeira vai assumir o lugar do dirigente-empresário.

Há um detalhe, no entanto, nessa iniciativa de Ricardo Teixeira: sua campanha tem início meses após Octávio Pinto Guimarães assumir a presidência, e quando o presidente da CBF sofre uma ameaça de impeachment, Teixeira posiciona-se a favor do afastamento de Octávio sob a justificativa que esse era o desejo de 22 das 26 federações que integravam a assembleia da CBF. ${ }^{49}$ Suspeita-se que a sua pressa teria a ver com o tratamento de um câncer no aparelho digestivo ao qual Octávio havia sido submetido.

\footnotetext{
${ }^{47}$ Rebelião no futebol. Folha de S. Paulo, 20 de julho de 1987, p. A2.

${ }^{48}$ Havelange havia apoiado a chapa que sairia derrotada por Octávio-Nabi.

${ }^{49}$ Genro de Havelange apoia o impeachment de Octávio. Folha de S. Paulo, 29 de setembro de 1987, p. A17.
} 
Dossiê | "Revolução com espírito empresarial": a criação do Clube dos 13 e a modernização do futebol na Folha de S. Paulo (GIGLIO, Sérgio Settani; SANTOS, João Manuel Casquinha Malaia)

Se não bastasse essa campanha precoce um outro fator colocava mais tensão na trama: Nabi Abi Chedid procurou Teixeira para compor uma chapa para a eleição seguinte. Sua ideia materializava em palavras como o campo (BOURDIEU, 1983) do futebol funciona: Nabi seria candidato à presidência em 1989 tendo Teixeira vice e, na eleição seguinte, na de 1992, Teixeira seria o candidato. Tal proposta não foi aceita por Teixeira e Nabi saia enfraquecido internamente dentro da $\mathrm{CBF}^{50} \mathrm{O}$ próprio Nabi aponta as divergências internas na CBF:

Com relação à administração, houve um choque de filosofia de trabalho, vamos dizer a verdade. [...] Eu entendia a forma para o campeonato brasileiro, qual esquema deveria ser - tanto que, das vezes que ele viajou, eu assumi a presidência da CBF - em 1986 eu estava afastado, devido ao problema eleitoral, à minha reeleição a deputado. Em 1987, fui eu quem formulou o campeonato - buscou uma solução no momento de crise, no momento em que ele viajou. Eu quem estabeleci os módulos, para poder ajustar uma posição de ordem esportiva e jurídica. Em 1988 aconteceu a mesma coisa. ${ }^{51}$

A leitura que se pode fazer desse desfecho da postura de Nabi é que ele já havia entendido que a formação do Clube dos 13, embora formalizada somente em julho de 1987, já estava em curso. Para ser apresentada naquele mês, muitos encontros foram realizados para construir a chamada "revolução" do futebol brasileiro. Se desse certo a organização de um campeonato brasileiro colocando a CBF em segundo plano, Nabi sabia que isso diminuiria suas chances de conseguir chegar ao centro do poder, à presidência da CBF. O fato é que a cada ação que ganhava corpo no cenário do futebol nacional colocava a gestão da CBF distante de conseguir transformar o futebol brasileiro exatamente porque voltava-se para a condição essencial do funcionamento de todo o sistema do futebol: o poder.

Enquanto a disputa pelo poder poderia revelar o que esperar do futuro do futebol brasileiro, a CBF reunia-se com 11 federações para definir como seria o campeonato brasileiro de 1987. Há menos de um mês do seu início, a pauta da discussão

\footnotetext{
${ }^{50}$ Nabi disputa com genro de Havelange a sucessão na CBF. Folha de S. Paulo, 20 de julho de 1987, p. A20.

${ }^{51}$ Entrevista de Nabi Abi Chedid ao programa Roda Viva da TV Cultura realizada em 09/01/1989. Disponível em: https://rodaviva.fapesp.br/materia_busca/287/nabi\%20abi\%20chedid/entrevistados/nabi_abi_chedid_ 1989.htm. Acesso em 10 de abril de 2021.
} 
Dossiê | "Revolução com espírito empresarial": a criação do Clube dos 13 e a modernização do futebol na Folha de S. Paulo (GIGLIO, Sérgio Settani; SANTOS, João Manuel Casquinha Malaia)

continuava em torno do número de clubes que deveria estar no campeonato e o consenso estava distante de ser conseguido. ${ }^{52} \mathrm{Nabi}$, por sua vez, recusava-se a ouvir a proposta do Clube dos 13: "Só recebo propostas das federações". 53

No entanto, mesmo sem querer conversar com o Clube dos 13, Nabi não tinha como escapar do debate com o grupo. A proposta já atingia um número muito superior àquele do início de todo o processo quando a CBF defendia um campeonato com 28 clubes. O inchaço que poderia levar a um campeonato com 64 clubes (divididos em quatro módulos - verde, amarelo, azul e branco) não era apenas um sintoma das dificuldades em organizar um campeonato nacional, mas escancarava o modus operandi de como funcionava o futebol brasileiro, pautado em uma lógica do clientelismo entre os dirigentes de clubes. Aidar voltava à cena para reforçar que o Clube dos 13 poderia até aceitar algumas mudanças do que pensavam desde que fossem garantidas algumas condições importantes, tais como o máximo de 16 clubes por módulo e que o campeão brasileiro seja do módulo do Clube dos 13. E completava:

O Clube dos Treze aceita qualquer outros três clubes para formarmos dezesseis e só jogaremos entre nós. Porém, no nosso módulo (verde) só pode haver descenso. Os grandes não ascenderão para outro módulo. [...] A segunda vaga para a Libertadores pode ser disputada entre o segundo do nosso módulo e um outro clube. ${ }^{54}$

A proposta apresentada pela Federação Paulista de Futebol (FPF) indicava uma possibilidade de consenso entre CBF e Clube dos 13. Porém, essa proposta possuía algumas diferenças do que Aidar havia apresentado quanto às garantias apresentadas. A proposta versava sobre a participação de 32 clubes divididos em três módulos, porém havia uma configuração para se chegar ao campeão:

De acordo com a proposta da FPF, os quatro melhores classificados do grupo verde, mais os três melhores do azul e o campeão do grupo amarelo fariam dois quadrangulares para decidir o título. Os quatro últimos colocados do grupo verde passariam para o azul e o último do grupo azul passaria para o amarelo. Os últimos colocados do grupo amarelo dariam lugar sempre aos campeões estaduais que estiverem fora do campeonato. ${ }^{55}$

\footnotetext{
${ }^{52}$ Nabi já admite Brasileiro com 62; Clube dos 13 rejeita. Folha de S. Paulo, 22 de julho de 1987, p. A16.

${ }^{53}$ Impasse adia decisão sobre o Brasileiro 87. Folha de S. Paulo, 21 de julho de 1987, p. A18.

${ }^{54}$ Clube dos Treze impõe condições para fazer acordo. Folha de S. Paulo, 23 de julho de 1987, p. A21.

${ }^{55}$ Clube dos Treze aceita proposta de dois grupos com 16 times para 87. Folha de S. Paulo, 26 de julho de 1987, p. A38.
} 
Dossiê | "Revolução com espírito empresarial": a criação do Clube dos 13 e a modernização do futebol na Folha de S. Paulo (GIGLIO, Sérgio Settani; SANTOS, João Manuel Casquinha Malaia)

A estratégia de dividir por módulos foi uma forma encontrada para não se falar em divisões, pois diante de uma falta de critério para definir quem ficaria em qual lugar optou-se por usar as cores de modo a não estruturar o futebol nacional em divisões. Por isso, a proposta da FPF fazia sentido ao misturar os módulos em um determinado momento do campeonato. Mesmo com esse discurso de não haver divisões no futebol brasileiro, na prática o que aconteceria era uma separação dos clubes em divisões. Os 13 clubes que lideravam o movimento queriam condições particulares para o módulo em que estariam e que se configuraria como o principal módulo. E as disputas estavam centradas com quem ficariam as três últimas vagas para compor a elite do futebol brasileiro. ${ }^{56}$

O imbróglio sobre a fórmula do campeonato, especialmente nas decisões sobre acesso e descenso colocava novamente a Justiça no caminho do futebol brasileiro. 0 chamado pacote do futebol vinha por meio das resoluções 16,17 e 18 do CND $^{57}$ que foram bloqueadas pelo Tribunal Federal de Recursos (TRF) via liminar da 6a Vara da Justiça de São Paulo, concedida a 17 federações. Desse modo, Manoel Tubino voltava ao centro do debate e acusava as federações de "agirem contra o futebol e contra a moralidade" ${ }^{58}$

A reação das federações foi imediata e solicitaram o afastamento de Tubino do cargo de presidente do CND. Exceto pela federação de São Paulo, as demais queriam o seu afastamento. Além disso, ficava estabelecido o campeonato brasileiro com 64 clubes divididos em quatro módulos com 16 clubes cada. ${ }^{59}$ Tubino, por sua vez, se defendia das acusações que recebia e reforçava que o processo democrático não interessava à maior parte dos dirigentes. Sua leitura daquele momento era que queria “[...] mudar a situação atual, porque faço parte de um governo que tem responsabilidade de ruptura com esta situação caótica. Desde o princípio sabíamos que

\footnotetext{
${ }^{56}$ CBF adia definição sobre o Brasileiro. Folha de S. Paulo, 28 de julho de 1987, p. A18.

57 "As resoluções se resumem no seguinte: institui a obrigatoriedade dos conselhos arbitrais nas federações de futebol e impõe voto qualitativo, em vez de unitário (16); cria divisões técnicas e fixa o número de clubes integrantes de cada divisão (17); e dispõe sobre o sistema de acesso e descenso dos clubes nos campeonato estaduais e nacional". Cf: CND vence mas não para Copa União. Folha de S. Paulo, 12 de setembro de 1987, p. A18.

58 TRF mantém liminar contra 'pacote do futebol' do CND. Folha de S. Paulo, 6 de agosto de 1987, p. A24. ${ }^{59}$ Federações pedem demissão de Tubino; 64 times disputam Brasileiro. Folha de S. Paulo, 7 de agosto de 1987, p. A16.
} 
Dossiê | "Revolução com espírito empresarial": a criação do Clube dos 13 e a modernização do futebol na Folha de S. Paulo (GIGLIO, Sérgio Settani; SANTOS, João Manuel Casquinha Malaia)

iríamos enfrentar bolsões de resistência, que fazem de tudo para se manter no poder" ${ }^{60}$ Em uma de suas entrevistas criticou o posicionamento dos dirigentes e tal fato provocou um confronto direto entre Tubino e Rubens Hoffmeister, presidente da Federação Gaúcha de Futebol. ${ }^{61}$

A figura do Tubino mostra-se como um ponto de equilíbrio nas disputas. Quando os embates não se resolviam, Tubino voltava à cena e aparecia nas notícias da Folha. Nesse jogo entre futebol e política é como se os dirigentes buscassem se aproximar do sentido mais clássico do uso da palavra política que é o seu vínculo com o Estado (RIBEIRO, 2012; 2020). E especificamente, Tubino era, juntamente, com o presidente da República, o grande representante do Estado. Em outras palavras, eles eram o refúgio dos dirigentes para conseguir seus objetivos e ter a chancela do Estado nas decisões.

Pode-se inferir que esse momento representa o estopim que confirma, após quase um mês, que o Clube dos 13 iria romper com a CBF e criar o seu próprio campeonato. ${ }^{62} \mathrm{~A}$ possibilidade da CBF em desfiliar os clubes que aderissem à Copa União era considerada apenas como uma ameaça já que, em termos de torcida, os clubes que participariam detinham a maioria de torcedores do país. ${ }^{63}$ As ameaças também versavam a respeito do veto da participação dos árbitros em relação a Copa União. ${ }^{64}$

O argumento de que os principais do Clube dos 13 aglutinavam $85 \%$ da preferência dos torcedores de futebol era o uso favorável da dimensão do torcer que os dirigentes se utilizavam. E como tal, deveriam investir na construção desse vínculo para ter as torcidas ao seu lado. Embora os dados tenham sido apresentados como sendo fruto de uma pesquisa sem detalhamento sobre quem a produziu ou quantas pessoas foram entrevistadas acabava por cumprir a sua principal condição, os dados apresentados abrangiam grande parte dos torcedores(as) brasileiros(as). A lógica posta era que tais números poderiam pressionar a CBF a aceitar a realização da Copa União. No entanto, não pode passar despercebido o fato de que o Clube dos 13 não somente buscou apoio das Torcidas Organizadas, como foi realizado o 1을 Congresso de Torcidas

\footnotetext{
${ }^{60}$ Dirigente se diz homenageado. Folha de S. Paulo, 7 de agosto de 1987, p. A16.

${ }^{61}$ Tubino e dirigente gaúcho tumultuam reunião do CND. Folha de S. Paulo, Folha de S. Paulo, 11 de agosto de 1987, p. A17.

${ }^{62}$ Clube dos Treze rompe com CBF e confirma Copa União. Folha de S. Paulo, 8 de agosto de 1987, p. A18.

63 Jurista não acredita em ameaça da CBF. Folha de S. Paulo, 9 de agosto de 1987, p. A40.

${ }^{64}$ Nabi diz que Copa é 'pirata'; juízes rebeldes serão punidos. Folha de S. Paulo, 2 de setembro de 1987, p. A17.
} 
Dossiê | "Revolução com espírito empresarial": a criação do Clube dos 13 e a modernização do futebol na Folha de S. Paulo (GIGLIO, Sérgio Settani; SANTOS, João Manuel Casquinha Malaia)

Organizadas dos Grandes Clubes do Futebol Brasileiro em Porto Alegre, sendo promovido pelo departamento de comunicação social do Internacional. ${ }^{65}$

A presença dessa informação sobre as torcidas é importante para entendermos como a presença delas se torna a legitimação das mudanças. Elas, no limite, funcionam para os dirigentes como um elemento de valorização quando se necessita de sua presença, especialmente, para justificar o motivo da escolha por determinados clubes para compor o campeonato, mas quando não se precisa delas, basta mantê-las afastadas.

Diante do cenário de disputas que envolviam os personagens até aqui apresentados pode-se inferir que o posicionamento de Nabi oscilava, mas logo se manteria irredutível na condição de oposição às propostas "revolucionárias" dos clubes. Se em alguns momentos parecia aceitar a proposta do Clube dos 13, em outros momentos posicionava-se de maneira totalmente contrária e considerava que a Copa União não existiria porque a CBF não iria autorizar a sua realização. ${ }^{66}$

Diante do impasse instaurado, o ministro da Educação, Jorge Bornhausen realizou uma audiência com Octávio Pinto Guimarães e Carlos Aidar, mas ressaltava que não poderia intervir por ser duas entidades privadas. ${ }^{67}$ Bornhausen também se posicionava contra o afastamento do presidente e vice-presidente da CBF solicitado por 22 federações por considerar antidemocrático e sem embasamento legal, ${ }^{68}$ mas que buscavam a convocação de uma assembleia geral para votar o impeachment de ambos. ${ }^{69}$ Ao longo dos meses a CBF conseguiu adiar a realização da assembleia ${ }^{70}$, mas o pedido de abertura de uma Comissão Parlamentar de Inquérito (CPI) queria investigar a CBF com a intenção de fazer "um raio $X$ do futebol brasileiro, em sua parte administrativa". ${ }^{71}$

Aidar seguia na linha de frente, mostrando a sua força diante de Nabi. Os clubes de São Paulo haviam apoiado a chapa Octávio-Nabi pelo fato de que defendiam uma

\footnotetext{
${ }^{65}$ Clube dos Treze já articula o apoio das torcidas a campeonato paralelo. Folha de S. Paulo, 28 de agosto de 1987, p. A18.

${ }^{66} \mathrm{CBF}$ adia a decisão sobre o Campeonato Brasileiro 87. Folha de S. Paulo, 11 de agosto de 1987, p. A17.

${ }^{67}$ CBF e Clube dos 13 discutem campeonato. Folha de S. Paulo, 13 de agosto de 1987, p. A16.

${ }^{68}$ Federações pedem demissão de Octávio e Nabi da CBF. Folha de S. Paulo, 18 de agosto de 1987, p. A15.

${ }^{69}$ Federações querem assembleia na CBF hoje. Folha de S. Paulo, 24 de agosto de 1987, p. A17.

${ }^{70}$ CBF obtém outra liminar e adia assembleia geral. Folha de S. Paulo, 16 de outubro de 1987, p. A22; CBF consegue adiar de novo assembleia geral. Folha de S. Paulo, 29 de outubro de 1987, p. A26.

${ }^{71}$ Mais de um terço do Congresso quer investigar CBF. Folha de S. Paulo, 4 de novembro de 1987, p. A22.
} 
Dossiê | "Revolução com espírito empresarial": a criação do Clube dos 13 e a modernização do futebol na Folha de S. Paulo (GIGLIO, Sérgio Settani; SANTOS, João Manuel Casquinha Malaia)

mudança institucional no futebol e perderam apoio dos paulistas quando não cumpriram as promessas da campanha. Aidar considerava a Copa União como algo irreversível e reforçava que Nabi não poderia punir os clubes que não participassem do campeonato brasileiro porque a participação dos clubes era feita via convite e os integrantes do Clube dos 13 iriam negar individualmente o convite. ${ }^{72}$

Todos os embates produzidos nessa caminhada de incertezas tinham como pano de fundo a dimensão financeira. Ao longo daquele ano de 1987 podemos inferir que o ponto de inflexão tenha sido a questão financeira. E por mais paradoxal que possa parecer, se a questão financeira inviabilizava a organização do campeonato por parte da CBF era exatamente esse fator que determinaria a realização da Copa União com a entrada do patrocínio da TV Globo para transmitir as partidas. Apresentada por Aidar como uma proposta vinda da Rede Globo de Cz\$170 milhões, bancando as passagens aéreas ${ }^{73}$, logo a rede de televisão informou que havia sido contatada pelo Clube dos $13 .^{74}$

Um artigo de opinião assinado pelo jornalista Luiz Carlos Caversan colocava a Rede Globo no centro do processo para a realização da Copa União e criticava a inabilidade de Aidar na condução no processo, especialmente pelo fato de o presidente do Clube dos 13 ter sido desmentido pela Rede Globo:

Muito mais do que obter a coesão de seus integrantes e demonstrar a força de suas torcidas, a Copa União terá que conseguir o acordo com a Rede Globo de Televisão, que é o único meio capaz de quebrar a hegemonia clientelista da Confederação Brasileira de Futebol (CBF). Se a Globo bancar a Copa, adquirindo os direitos de transmissão dos jogos, será o fim da CBF. Com a força de uma das mais bem estruturadas redes de TV do mundo por trás, quem vai precisar de entidade politicamente manipulável e que mais problemas acarreta ao futebol do que benefícios concretos a clubes e torcedores? ${ }^{75}$

A análise de Caversan colocava uma divisão binária, certamente, percebida naquele momento em que a entrada da Rede Globo representaria o fim da CBF. Em que

\footnotetext{
${ }^{72}$ Globo oferece 170 mi para mostrar Copa União, diz Aidar. Folha de S. Paulo, 31 de agosto de 1987, p. A17.

${ }^{73} \mathrm{Idem}$.

${ }^{74}$ Globo nega acordo mas estuda proposta dos clubes. Folha de S. Paulo, 10 de setembro de 1987, p. A16.

${ }^{75}$ CAVERSAN, Luiz Carlos. Novo torneio precisa da televisão. Folha de S. Paulo, 10 de setembro de 1987, p. A16.
} 
Dossiê | "Revolução com espírito empresarial": a criação do Clube dos 13 e a modernização do futebol na Folha de S. Paulo (GIGLIO, Sérgio Settani; SANTOS, João Manuel Casquinha Malaia)

pese isso não se concretizar quando observamos os rumos que o futebol brasileiro tomou após 1987. A hegemonia clientelista que o jornalista imaginava que seria quebrada tampouco aconteceu, afinal, a sequência das eleições para a presidência da CBF colocou Ricardo Teixeira no poder.

O imbróglio todo parecia estar perto do fim. A CBF aceitou o acordo com o Clube dos $13^{76}$ e a Rede Globo assinou o contrato de transmissão dos jogos por aproximadamente $\mathrm{Cz} \$ 166$ milhões ${ }^{77} \mathrm{~A}$ Varig ficou como patrocinadora do campeonato e cuidaria do transporte dos clubes. E havia, ainda, a possibilidade de se conseguir outros patrocinadores. Isso aconteceu efetivamente depois do início do campeonato. Desse modo, as empresas Coca-Cola, Banco Bamerindus, Ray O Vae, Caninha 51, Gillette, Sul América Seguros e Açúcar União eram candidatos a patrocinar o campeonato e buscavam colocar suas marcas no centro do gramado. A comercialização do círculo central seria feita por Cz\$75 milhões. $^{78}$

A Coca-Cola ofereceu cerca de $\mathrm{Cz} \$ 867$ milhões para ser a única patrocinadora da Copa União. A ação da Coca-Cola não pode ser lida somente pela vista da exclusividade, mas refletia uma ação da empresa em conter o retorno ao Brasil da concorrente Pepsi. ${ }^{79} \mathrm{O}$ contrato previa "[...] anúncios no círculo central dos estádios onde forem realizados jogos do torneio, nas placas publicitárias ao redor do gramado, nos vestiários e na TV Globo". Além dessas ações, nove clubes passariam a estampar a marca da empresa em suas camisas - Fluminense, Vasco, Botafogo, Atlético-MG, Cruzeiro, Bahia, Goiás e Santa Cruz -, sendo que para o ano de 1988 todas as equipes deveriam contar com o patrocínio da Coca-Cola em seus uniformes. ${ }^{80}$

No entanto, o contrato de cinco anos não foi firmado imediatamente. Levou alguns dias até que o acordo entre Coca-Cola, Clube dos 13 e Rede Globo fosse

\footnotetext{
${ }^{76} \mathrm{CBF}$ anuncia acordo com Clube dos Treze. Folha de S. Paulo, 4 de setembro de 1987, p. A16.

77 Globo paga 166 mi para mostrar o Brasileiro. Folha de S. Paulo, 5 de setembro de 1987, p. A16.

${ }^{78}$ Clube dos 13 negocia círculo central dos estádios por 75 mi. Folha de S. Paulo, 30 de setembro de 1987, p. A19.

${ }^{79}$ Coca e Pepsi disputam consumidores nos supermercados. Folha de S. Paulo, 1ㅇ de outubro de 1987, Negócios, p. 4; Alguns meses depois há outra notícia sobre o avanço da Pepsi no Brasil: Pepsi investe em cadeia de restaurantes. Folha de S. Paulo, 23 de dezembro de 1987, Negócios, p. 3.

${ }^{80}$ Clube dos Treze vende meio-campo por US\$ 17 milhões. Folha de S. Paulo, 1ㅇ de outubro de 1987, p. A25. Havia um contrato menor, com a editora Abril, para a confecção do álbum de figurinhas do campeonato (cerca de Cz\$2 28 milhões).
} 
Dossiê | "Revolução com espírito empresarial": a criação do Clube dos 13 e a modernização do futebol na Folha de S. Paulo (GIGLIO, Sérgio Settani; SANTOS, João Manuel Casquinha Malaia)

fechado. ${ }^{81}$ Finalmente, no dia 9 de outubro, o contrato foi assinado e foi realizada a primeira pintura no círculo central no estádio do Morumbi, ${ }^{82}$ ação essa que foi contestada pela FIFA uma infração à regra número 1: o campo de jogo ${ }^{83}$.

Para Aidar, o que estava em jogo diante da proibição da FIFA quanto a propaganda no círculo central era "uma medida política para enfraquecer o Clube dos Treze" [...] com o objetivo de "fortalecer a candidatura de Ricardo Teixeira à presidência da CBF". Essa linha argumentativa, por certo, não se sustenta, pois a própria FIFA cobrou a CBF sobre a não convocação das assembleias que estavam sendo solicitadas por grande parte das federações. ${ }^{84}$ De um ponto de vista mais imediato é preciso fazer uma leitura econômica do caso, afinal, com o impedimento de colocar a sua marca no gramado a Coca-Cola poderia reduzir em $50 \%$ o valor do contrato com o Clube dos $13^{85}$ e enquanto a situação não era definida a empresa suspendeu os pagamentos. ${ }^{86} \mathrm{~A}$ solução encontrada para resolver a questão era a inclusão do logotipo da empresa nos uniformes dos clubes nos campeonatos estaduais de 1988. Quatro clubes, porém, não fecharam o acordo: Corinthians, Flamengo, Palmeiras e Internacional. ${ }^{87}$

A resposta do Clube dos 13 vinha por duas vias distintas. A primeira foi a de acusar a FIFA de ser ditatorial e promover uma intervenção reacionária. ${ }^{88} \mathrm{~A}$ segunda era a mudança do lugar de publicização da marca da Coca-Cola, agora ela saía do círculo central e ia para dentro do gol ${ }^{89}$, mas essa proposta foi rapidamente descontinuada. ${ }^{90}$

\footnotetext{
${ }^{81}$ Coca-Cola acerta hoje patrocínio da Copa União. Folha de S. Paulo, 7 de outubro de 1987, p. A18; 'Detalhes' adiam de novo acordo da Coca-Cola com a Copa. Folha de S. Paulo, 8 de outubro de 1987, p. A21.

${ }^{82}$ Contrato bilionário muda o visual do Morumbi. Folha de S. Paulo, 10 de outubro de 1987, p. A16.

${ }^{83}$ Marca da Coca-Cola nos estádios é ilegal, afirma instrutor da Fifa. Folha de S. Paulo, 14 de outubro de 1987, p. A18; Fifa condena logotipo da Coca-Cola no campo. Folha de S. Paulo, 15 de outubro de 1987, p. A19.

${ }^{84}$ Fifa questiona a CBF. Folha de S. Paulo, 20 de outubro de 1987, p. A15.

${ }^{85}$ Aidar desafia Fifa e mantém logotipo no campo. Folha de S. Paulo, 16 de outubro de 1987, p. A22.

${ }^{86}$ Coca-Cola suspende pagamento aos clubes. Folha de S. Paulo, 27 de outubro de 1987, p. A22.; CocaCola deixa de pagar 30\% do contrato. Folha de S. Paulo, 2 de novembro de 1987, p. A19.

${ }^{87}$ Times aceitam a proposta da Coca-Cola. Folha de S. Paulo, 10 de novembro de 1987, p. A22.

${ }^{88}$ Clube dos Treze acusa a Fifa de ser ditatorial. Folha de S. Paulo, 19 de outubro de 1987, p. A22.

${ }^{89}$ Clube dos Treze decide colocar Coca-Cola dentro do gol. Folha de S. Paulo, 20 de outubro de 1987, p. A15.

${ }_{90}$ Aidar desiste de colocar Coca-Cola dentro do gol. Folha de S. Paulo, 21 de outubro de 1987, p. A20.
} 
Dossiê | "Revolução com espírito empresarial": a criação do Clube dos 13 e a modernização do futebol na Folha de S. Paulo (GIGLIO, Sérgio Settani; SANTOS, João Manuel Casquinha Malaia)

\section{O prestígio da CBF em jogo}

As divergências internas da CBF materializadas por meio do presidente e do vicepresidente revelavam, para a Folha, que a grande derrotada do processo era a CBF. ${ }^{91}$ Octávio e Nabi há muito tempo não estavam em sincronia, pelo contrário. ${ }^{92}$ Enquanto Octávio entendia que a criação da Copa União era uma saída importante para a CBF pelo fato de não ter dinheiro para organizar o campeonato nacional, Nabi sabia que os dirigentes dos clubes que estavam à frente do Clube dos 13 ganhariam muita força no cenário do futebol nacional. As divergências entre ambos podem ser vistas nas falas quando a Copa União estava prestes a se iniciar. De um lado Octávio disse: “Mas Nabi você acha que vou brigar com a Rede Globo?" e Nabi respondeu: "Você está mais preocupado com a Globo do que com o futebol brasileiro". ${ }^{93}$

Um dos pontos centrais da divergência na cúpula da CBF estava na insistência de Nabi querer mandar no futebol brasileiro. Essa função de coordenador de futebol da $\mathrm{CBF}$, no entanto, havia sido dada a ele por meio dos acordos de apoio entre os grupos que compuseram a chapa de Octávio. ${ }^{94}$ Esse apoio garantiu a vitória e "Aidar tentou convencer Octávio de que essa atitude não beneficiaria o futebol brasileiro mas acabaria por fortalecer seu adversário político, Nabi Abi Chedid". ${ }^{95}$

\footnotetext{
${ }^{91}$ Crise revela desorganização da CBF. Folha de S. Paulo, 7 de setembro de 1987, p. A18.

92 Sobre essas divergências, Nabi fala no programa Roda Viva em 1989: "Perfeitamente, então eu era favorável a uma descentralização administrativa, a cursos e simpósios, que a FIFA oferece graciosamente. [...] Eu entendia a forma para o campeonato brasileiro, qual esquema deveria ser - tanto que, das vezes que ele viajou, eu assumi a presidência da CBF - em 1986 eu estava afastado, devido ao problema eleitoral, à minha reeleição a deputado. Em 1987, fui eu quem formulou o campeonato - buscou uma solução no momento de crise, no momento em que ele viajou. Eu quem estabeleci os módulos, para poder ajustar uma posição de ordem esportiva e jurídica. Em 1988 aconteceu a mesma coisa. [Fui eu] quem pediu aos clubes, às federações, ao CND, para que houvesse um pleno entendimento e, em razão disto, o professor Manoel Tubino implantou as resoluções 16, 17 e 18, que retiravam o poder da própria CBF [e] das federações - federações estas, que tinham entrado na Justiça comum para derrubar estas resoluções e não conseguiram. Através do diálogo, do entendimento, reunido em agosto com os clubes [e] com as federações - que possuem clubes que iam disputar a chamada primeira divisão do futebol brasileiro -, nós chegamos a um entendimento, e houve a resolução 11/1988 do CND, que devolveu o poder à CBF". Disponível em: https://rodaviva.fapesp.br/materia_busca/287/nabi\%20abi\%20chedid/entrevistados/nabi_abi_chedid_ 1989.htm. Acesso em: 1ㅇde abril de 2021.

93 TV faz Nabi chamar Octávio de 'safado'. Folha de S. Paulo, 11 de setembro de 1987, p. A16.

${ }^{94}$ Federações tentam retomar poder dado a Octávio. Folha de S. Paulo, 25 de setembro de 1987, p. A18.

95 Octávio Guimarães diz que renúncia à presidência da CBF. Folha de S. Paulo, 17 de setembro de 1987, p. A17.
} 
Dossiê | "Revolução com espírito empresarial": a criação do Clube dos 13 e a modernização do futebol na Folha de S. Paulo (GIGLIO, Sérgio Settani; SANTOS, João Manuel Casquinha Malaia)

Diante do cenário em que a CBF perdia seu prestígio e credibilidade parecia que ela não possuía outra alternativa a não ser aceitar a proposta da Copa União ${ }^{96}$, mas Nabi aparecia para questionar o andamento do processo. Mas não era somente Nabi que estava nesse jogo. Havia a suspensão das resoluções 16, 17 e 18 do CND e, se fossem revogadas atingiriam frontalmente a proposta do Clube dos 13 de não haver times rebaixados e times que teriam direito ao acesso ao módulo principal. Nabi era enfático ao dizer que o Clube dos 13 e a Copa União eram uma pirataria, avaliava que o futebol estava em perigo por conta da transmissão das partidas de futebol pela televisão aos domingos: "é a morte do futebol. De repente, a televisão fica mais importante que a entidade. Isso não posso permitir". ${ }^{97}$

Grande parte dos clubes excluídos do módulo verde estava insatisfeita com a proposta da Copa União. A barganha por uma vaga no campeonato nacional estava instituída como uma ação do jogo político dos dirigentes. Os clubes que estavam colocados no módulo amarelo queriam uma fase final com o módulo verde, a Copa União, além do recebimento de 32\% da quantia acordada com a Rede Globo. O dirigente Eurico Miranda, vice-presidente do Vasco e representante do Clube dos 13, era irredutível diante das propostas e somente aceitava repassar $10 \%$ dos valores televisivos para o módulo amarelo. ${ }^{98}$ Aidar completava que a possibilidade de jogos entre o campeão e vice do módulo verde e amarelo eram para decidir, em um quadrangular, qual clube brasileiro disputaria a Libertadores da América do ano seguinte. ${ }^{99}$

A criação dos módulos por cores foi uma tentativa de dizer que não havia a estratificação do futebol brasileiro por divisões. No entanto, o Clube dos 13 ao estabelecer as cores e propor que determinados clubes ficassem em um módulo considerado o principal causava problemas no cenário futebolístico brasileiro. A CBF, por sua vez, como forma de evitar o inevitável diante da insatisfação de quem não pertencia ao seleto grupo, ou seja, se ela considerasse o módulo verde como sendo o campeonato brasileiro da primeira divisão sabia que sofreria uma pressão dos

\footnotetext{
${ }^{96}$ CBF divulga tabela; Clube dos 13 acerta patrocínio. Folha de S. Paulo, 8 de setembro de 1987, p. A20.

97 Nabi segura tabela; Copa União pode ser adiada. Folha de S. Paulo, 9 de setembro de 1987, p. A16.

98 Nabi diz que Brasileiro começa, 'doa a quem doer'. Folha de S. Paulo, 10 de setembro de 1987, p. A22.

${ }^{99}$ Copa União começa hoje, com apoio da CBF. Folha de S. Paulo, 11 de setembro de 1987, p. A16.
} 
Dossiê | "Revolução com espírito empresarial": a criação do Clube dos 13 e a modernização do futebol na Folha de S. Paulo (GIGLIO, Sérgio Settani; SANTOS, João Manuel Casquinha Malaia)

preteridos $^{100}$ e de algumas federações ${ }^{101}$, por isso tinha como proposta e vinha defendendo que deveria haver o cruzamento do campeão do módulo verde com o do amarelo para definir quem seria o campeão brasileiro daquele ano. ${ }^{102}$

A Copa União havia começado, mas os problemas ainda persistiam. Iam desde as insatisfações já mencionadas pelos clubes do módulo amarelo, passando pelo pedido de impeachment do presidente da $\mathrm{CBF}^{103}$ que acionava a sucessão da presidência da entidade ${ }^{104}$, e também pelas reivindicações do Clube dos 13 junto a CBF. ${ }^{105}$ No dia 22 de setembro houve uma reunião entre a CBF e o Clube dos 13 que selou um acordo que representava algumas conquistas ao Clube dos 13, entre as quais estavam, "a extinção da cota de $5 \%$ da renda dos clubes do módulo verde que eram repassados às federações, extinção da retirada de $\mathrm{Cz} \$ 2,00$ de cada ingresso para a CBF organizar os torneios de incentivos [...]", porém, uma ponta ainda permanecia aberta: o regulamento que estabeleceria o cruzamento entre os módulos verde e amarelo. ${ }^{106}$

O tema da desorganização do futebol brasileiro voltava a compor o editorial da Folha. Sob o título Jogo perdido o editorial pontuava a liderança da Federação Paulista de Futebol na busca pela destituição da presidência da CBF. No entanto, entendia que pouco mudaria porque havia uma forma de organizar o futebol em que "abriga e reproduz burocratas ineptos e toda sorte oportunismos, conchavos, jogos de interesse e concessões - o principal obstáculo para a instituição do que poderia ser uma gestão moderna do esporte". ${ }^{107}$ Embora o editorial buscasse na crítica explicitar sobre o modus operandi da estrutura que impedia a produção de outro tipo de futebol, a perspectiva da mudança por parte do jornal seria efetivada a partir de uma gestão empresarial do futebol.

100 Rebelião no módulo amarelo ameaça o Brasileiro 87. Folha de S. Paulo, 13 de setembro de 1987, p. A34; Módulo amarelo vai tentar parar campeonato na Justiça. Folha de S. Paulo, 14 de setembro de 1987, p. A18; Ameaça do módulo amarelo não preocupa Aidar. Folha de S. Paulo, 15 de setembro de 1987, p. A16.

${ }^{101}$ Federações agem para impeachment de Octávio. Folha de S. Paulo, 18 de setembro de 1987, p. A16.

102 CND vence mas não para a Copa União. Folha de S. Paulo, 12 de setembro de 1987, p. A18; Campeão de 87 será conhecido no início de 88. Folha de S. Paulo, 2 de outubro de 1987, p. A17.

103 Presidente anuncia assembleia geral. Folha de S. Paulo, 22 de setembro de 1987, p. A20; Impeachment contra Octávio e Nabi tem apoio de Marin. Folha de S. Paulo, 24 de setembro de 1987, p. A18.

${ }^{104}$ Braga lança Aidar, líder dos Treze, à presidência da CBF. Folha de S. Paulo, 19 de setembro de 1987, p. A17.

105 Clube dos Treze dá ultimato à Confederação. Folha de S. Paulo, 22 de setembro de 1987, p. A20.

106 Pressionada, CBF faz acordo com Clube dos 13. Folha de S. Paulo, 23 de setembro de 1987, p. A18.

107 Jogo perdido. Folha de S. Paulo, 28 de setembro de 1987, p. A2. 
Dossiê | "Revolução com espírito empresarial": a criação do Clube dos 13 e a modernização do futebol na Folha de S. Paulo (GIGLIO, Sérgio Settani; SANTOS, João Manuel Casquinha Malaia)

Visão essa que também era compartilhada por jornalistas da Folha que reforçava dois lugares que percorreram o ano de 1987: diante da crise do futebol que gera a desorganização é preciso romper com a política clientelista e implementar a gestão empresarial. E a Copa União era o marco desse sucesso mesmo que alguns erros pudessem ser corrigidos, como jogos no sábado à noite; o segundo ponto era a "administração moderna" do São Paulo e não à toa Carlos Aidar acumulava o cargo de presidente do São Paulo e do Clube dos $13 .{ }^{108}$

Interessante notar que a Copa União era vista como uma revolução dentro do futebol brasileiro, que alterava o modo como a gestão organizacional vinha sendo feita pela CBF. Mas uma mudança no estatuto do Clube dos 13 para permitir a reeleição Aidar $^{109}$ para o cargo de presidente não era vista como uma antiga prática do futebol brasileiro, a permanência no cargo por parte dos dirigentes que remetiam a uma estrutura de oligaquização do futebol brasileiro. ${ }^{110}$ Mudar o estatuto é uma das formas pelas quais a modernização conservadora se manifesta (OURIQUES, 1998).

Mais um editorial da Folha fazia uma análise do futebol brasileiro e voltava a reiterar que não haveria mágica para acabar com o "processo de decadência e desmoralização" do futebol nacional. A saída era aquela que o jornal já havia apontado inúmeras vezes: a gerência do esporte precisava ser mais "criativa, moderna e empresarial" ${ }^{111}$

Apesar de a Copa União querer produzir "um futebol melhor", revolucionário ou inovador, até aquele momento ainda havia o impasse sobre a definição de quem seria o campeão brasileiro de 1987, fato que persistiu até o final da competição. ${ }^{112}$ Por meio

\footnotetext{
${ }^{108}$ ALONSO, George. Desinformação prejudica campeonato. Folha de S. Paulo, 3 de outubro de 1987, p. A15.

${ }^{109}$ Naquele momento havia a oposição de dois clubes: Cruzeiro e Corinthians. O presidente do Cruzeiro, Benito Masei, tentou se candidatar mas ninguém quis compor a chapa e Vicente Mateus, presidente do Corinthians, mostava-se contrariado com o patrocínio da Coca-Cola para as camisas de futebol, pois não queria trocar o seu tradicional patrocinador, a Kalunga. Cf: Aidar é eleito o melhor entre 'caciques'. Folha de S. Paulo, 18 de dezembro de 1987, p. A20.

${ }^{110}$ Clube dos Teze altera estatuto para reeleger Aidar. Folha de S. Paulo, 17 de dezembro de 1987, p. A32.

111 Um futebol melhor. Folha de S. Paulo, 15 de dezembro de 1987, p. A2.

${ }^{112}$ Campeão brasileiro só deve ser definido após reunião da CBF. Folha de S. Paulo, 14 de dezembro de 1987, p. A21; CBF pode marcar outro jogo para definir campeão do módulo amarelo. Folha de S. Paulo, 15 de dezembro de 1987, p. A24.
} 
Dossiê | "Revolução com espírito empresarial": a criação do Clube dos 13 e a modernização do futebol na Folha de S. Paulo (GIGLIO, Sérgio Settani; SANTOS, João Manuel Casquinha Malaia)

desse impasse em relação ao regulamento, voltava à tona as disputas de poder entre a CBF e clube dos $13 .{ }^{113}$

Embora a Copa União de 1987 tivesse sido finalizada, o impasse sobre o regulamento persistia. acordo entre a CBF e o Clube dos 13 definia o Flamengo como campeão da Copa União sendo, portanto, campeão brasileiro. A proposta definida na reunião ainda seria homologada, de modo que também estabelecia que mais quatro clubes seriam incorporados ao módulo verde em 1988 (Guarani, Sport, Bangu e AtléticoPR - semifinalistas do módulo amarelo) e que Flamengo e Internacional, campeão e vice do módulo verde seriam os representantes brasileiros na Libertadores de $1988 .{ }^{114}$

Sem um comunicado oficial por parte da CBF, o Guarani se posicionava contrário ao que havia sido decidido por entender que o acordo com a CBF era outro e deveria acontecer o cruzamento dos módulos para se chegar ao campeão brasileiro. ${ }^{115}$ Dias depois, Octávio Pinto, defendia o cruzamento entre os módulos verde e amarelo ${ }^{116}$, além de minimizar o fato de que Sport e Guarani, após empatarem em 11 a 11 na cobrança de pênaltis, decidiram dividir o título do módulo amarelo. ${ }^{117}$ Apesar desse episódio, pelos critérios da CBF ambos deveriam jogar o quadrangular final para se chegar ao campeão brasileiro daquele ano. O quadrangular foi jogado entre janeiro e fevereiro de 1988, mas Flamengo e Inter não entraram em campo. Na última partida, o Sport venceu o Guarani por 1 a 0 e comemorou o título de campeão brasileiro. ${ }^{118}$

Terminamos o ano de 1987 do mesmo jeito que começou em relação ao futebol. Muitas disputas, muitos acordos e desacordos mostravam como se constituía o jogo de forças do futebol brasileiro naquele momento. Havia, porém, um elemento que não sairia mais do jogo: a presença do discurso empresarial como sinônimo de sucesso.

\section{Considerações finais}

\footnotetext{
113 Braga desafia Nabi a contestar tetracampeonato do Flamengo. Folha de S. Paulo, 15 de dezembro de 1987, p. A24.

${ }^{114}$ CBF reconhece tetra do Fla; Copa União terá 20 clubes. Folha de S. Paulo, 18 de dezembro de 1987, p. A20.

115 Guarani não aceita acordo entre CBF e Clube dos Treze. Folha de S. Paulo, 19 de dezembro de 1987, p. A24.

116 Octávio exige quadrangular para definir campeão de 87. Folha de S. Paulo, 22 de dezembro de 1987, p. A22.

${ }^{117}$ Sorteio poderá definir título do módulo amarelo. Folha de S. Paulo, 27 de dezembro de 1987, p. A31; CBF adia decisão sobre título do amarelo. Folha de S. Paulo, 29 de dezembro de 1987, p. A17.

${ }^{118}$ Sport faz carnaval na conquista do torneio da CBF. Folha de S. Paulo, 8 de fevereiro de 1988, p. A23.
} 
Dossiê | "Revolução com espírito empresarial": a criação do Clube dos 13 e a modernização do futebol na Folha de S. Paulo (GIGLIO, Sérgio Settani; SANTOS, João Manuel Casquinha Malaia)

Ao analisar a formação da Copa União de 1987 no jornal Folha de S. Paulo encontramos os caminhos das disputas pelo controle do futebol no país. Em nome da mudança, da revolução e da construção de um novo futebol pode-se inferir que houve apenas uma reforma que não alterou, de fato, a estrutura do futebol brasileiro. As promessas de antes tornam-se promessas do futuro. Estava em curso a modernização conservadora do futebol brasileiro em que os envolvidos assumiram novas roupagens na administração do futebol. As pessoas influentes do cenário futebolístico continuaram a disputar seu espaço no controle do futebol nacional.

O alinhamento da Folha com a ideia de que mudança do futebol brasileiro teria que passar pela administração empresarial do futebol foi reforçada em várias oportunidades. Conforme apontamos, essa visão estava muito bem alinhada com o seu novo projeto editorial. Quando pensamos especificamente no futebol podemos inferir que em muitas delas, podemos destacar o espaço dado - seja por meio de fotos ou reportagens que tratavam Carlos Aidar como a pessoa que havia mudado a gestão do São Paulo Futebol Clube e, por meio, do Clube dos 13 começava a realizar uma mudança mais ampla. Em um desses espaços, Aidar escrevia um artigo de opinião em que apontava as mudanças e valorizava a ação dos clubes. Em outros momentos possuía um grande espaço, como uma entrevista de uma página inteira no jornal ${ }^{119}$. Vendo o enfraquecimento da CBF propunha a criação da Federação Brasileira de Futebol Profissional. ${ }^{120}$

No discurso da Folha, era como se Aidar tivesse o "espírito empresarial", expressão utilizada em um de seus editoriais para justificar a necessidade de uma gestão eficiente. Se Aidar tinha isso, logo ele era o oposto da dupla Octávio-Nabi que apareciam mostrando a ineficiência da CBF em se organizar administrativamente.

O caso de um empreendimento bem sucedido da Copa União era apresentado na Folha especialmente em relação ao sucesso tanto financeiro ${ }^{121}$ quanto televisivo. Isto

\footnotetext{
${ }^{119}$ Aidar afirma que falta competência à imprensa esportiva. Folha de S. Paulo, 14 de dezembro de 1987, p. A24.

${ }^{120}$ AIDAR, Carlos Miguel. Apoiado pela opinião pública, movimento aponta novo rumo. Folha de S. Paulo, 11 de outubro de 1987, p. A26.

${ }^{121}$ RANGEL, Renata. Estratégia de mercado rende Cz\$357 mi ao Clube dos 13. Folha de S. Paulo, 11 de outubro de 1987, p. A24; Copa União arrecada Cz\$293 mi fora das bilheterias. Folha de S. Paulo, 20 de dezembro de 1987, p. A52.
} 
Dossiê | "Revolução com espírito empresarial": a criação do Clube dos 13 e a modernização do futebol na Folha de S. Paulo (GIGLIO, Sérgio Settani; SANTOS, João Manuel Casquinha Malaia)

provocava o que Bourdieu (1997) aponta ser uma das características da televisão: ela oculta mostrando. Ao mostrar o futebol do módulo verde como um produto de destaque acabava por ocultar que o futebol brasileiro era muito mais amplo do que os chamados "grandes clubes". Evidenciava-se assim como algo legítimo o monopólio do futebol nacional reservado às grandes marcas. Vinculado ao capital, o futebol respirava. Era apontado nas análises que somente a gestão empresarial poderia alterar a estrutura viciada do futebol brasileiro.

A lógica do clientelismo, da desorganização da CBF e das disputas de interesses entre os clubes de futebol continuaram, mesmo com a criação da Copa União. Uma das grandes mudanças introduzida anos antes da criação da Copa União foi a autorização da propaganda nas camisas dos clubes de futebol. Associada com a entrada da Rede Globo de televisão como grande patrocinadora da competição nacional do futebol brasileiro, são dois pontos de inflexão que alteram definitivamente a modalidade.

A decisão do Clube dos 13 em não fazer acesso e descenso para o campeonato que organizava era a prova de que os clubes "grandes" haviam fechado um pacto interno para mantê-los em uma lógica de que eram, de fato, os clubes brasileiros mais importantes e por isso deveriam obter o monopólio da organização do futebol no país; além disso, era condição do regulamento que mostrava o quanto pretendiam se distinguir dos demais clubes nacionais. Afinal, a CBF queria jogos entre os módulos para as fases finais, algo que foi sendo negado em todas as oportunidades pelos dirigentes do Clube dos 13. A distinção clubística era vista como uma forma de garantir bons jogos. Havia a ideia de que agrupando os melhores clubes do Brasil em um único módulo, a qualidade do jogo seria garantida. No entanto, essa condição foi logo contestada quando a qualidade não foi o que se esperava. ${ }^{122}$

Sob a chancela do discurso "revolucionário", da gestão empresarial, naquele tempo ainda chamado de "futebol-empresa", tinha o apoio das pessoas que clamavam por mudanças no futebol. Entre elas, estavam os jornalistas que assinaram inúmeros textos na Folha bem como o próprio jornal por meio de seus editorais que defendiam a necessidade de superação do atraso dos dirigentes. Pelo caminho percorrido, buscamos entender como a modernização conservadora não produziu uma mudança estrutural,

\footnotetext{
122 Globo pode reduzir transmissões da Copa União, diz Aidar. Folha de S. Paulo, 26 de outubro de 1987,
} p. A19. 
Dossiê | "Revolução com espírito empresarial": a criação do Clube dos 13 e a modernização do futebol na Folha de S. Paulo (GIGLIO, Sérgio Settani; SANTOS, João Manuel Casquinha Malaia)

longe disso. Apenas, revelou as disputas de poder dos dirigentes que queriam ocupar outro lugar dentro do campo esportivo (BOURDIEU, 1983). E o que estava em jogo era o controle do monopólio do futebol brasileiro e não a sua mudança. Não se podia esperar muito mais de uma "revolução" feita com "espírito empresarial".

\section{Referências}

ANDREFF, Wladimir e SZYMANSKI, Stefan. Handbook on the Economics of Sport. Cheltenham, Reino Unido: Edward Elgar, 2007.

BOURDIEU, Pierre. Como é possível ser esportivo? In: Questões de Sociologia. Rio de Janeiro: Marco Zero, 1983.

Sobre a Televisão. Rio de Janeiro, Jorge Zahar, 1997.

FORSTER, John e POPE, Nigel. The Political Economy of Sports Organisations. Londres: Routledge, 2004.

GIGLIO, Sérgio Settani. A história política do futebol olímpico (1894-1988). São Paulo: Intermeios/FAPESP, 2018.

GIULIANOTTI, Richard. Football: A Sociology of the Global Game. Cambridge: Polity Press, 1999.

GODDARD, John. "The Economics of soccer". In: ANDREFF, Wladimir e SZYMANSKI, Stefan. Handbook on the Economics of Sport. Cheltenham, Reino Unido: Edward Elgar, 2007, p.451-458.

HELAL, Ronaldo. Passes e Impasses: futebol e cultura de massa no Brasil. Campinas: Vozes, 1997.

LUCA, Tânia Regina de. História dos, nos e por meio de periódicos. In: PINKSY, Carla Bassanesi (org.). Fontes Históricas. São Paulo: Contexto, 2008, p. 111-154.

OURIQUES, Nilso Domingos. A modernização conservadora do futebol nacional. 1998. 175 f. Dissertação (Mestrado em Sociologia) - Universidade Federal de Santa Catarina, Florianópolis, 1998.

PRONI, Marcelo Weishaupt. A Metamorfose do Futebol. Campinas: Unicamp, 2000.

O futebol-empresa no Brasil. In: GIGLIO, Sérgio Settani; PRONI, Marcelo Weishaupt. (Orgs.). O futebol nas ciências humanas no Brasil. Campinas: Editora da Unicamp, 2020.

RIBEIRO, Luiz Carlos. Futebol: por uma história política da paixão nacional. História: Questões \& Debates. Curitiba, n. 57, p. 15-43, 2012.

. Futebol e política. In: GIGLIO, Sérgio Settani; PRONI, Marcelo Weishaupt. (Orgs.). O futebol nas ciências humanas no Brasil. Campinas: Editora da Unicamp, 2020.

ROCHA, Luiz Guilherme Burlamaqui Soares Porto. Os empresários, a pátria e a bola: nacionalismo, organização empresarial e o financiamento da seleção brasileira de futebol de 1970. Estudos Históricos. Rio de Janeiro, v. 32, n. 68, p. 655-674, 2019.

ROCHA, Max Filipe Nigro. Em busca do feitiço perdido: a revista Placar entre a Seleção Brasileira de 1982, a Revolução São-Paulina e a Democracia Corintiana (1979 -1984). 2013. 225 
Dossiê | "Revolução com espírito empresarial": a criação do Clube dos 13 e a modernização do futebol na Folha de S. Paulo (GIGLIO, Sérgio Settani; SANTOS, João Manuel Casquinha Malaia)

f. Dissertação (Mestrado em História) - Faculdade de Filosofia, Letras e Ciências Humanas, Universidade de São Paulo, São Paulo, 2013.

RODRIGUES, Francisco Xavier Freire. 0 fim do passe e a modernização conservadora no futebol brasileiro (2001-2006). 2007. 346 f. Tese (Doutorado em Sociologia) - Instituto de Filosofia e Ciências Humanas, Universidade Federal do Rio Grande do Sul, Porto Alegre, 2007.

SANTOS, Anderson David Gomes dos. A consolidação de um monopólio de decisões: A Rede Globo e a transmissão do Campeonato Brasileiro de Futebol. 2013. 268 f. Dissertação (Mestrado em Comunicação) - Unidade Acadêmica de Pesquisa e Pós-graduação, Universidade do Vale do Rio dos Sinos, São Leopoldo, 2013.

SANTOS, João Manuel Casquinha Malaia. O Monopólio nos Esportes: uma comparação da organização dos esportes comercializáveis nos Estados Unidos, na Inglaterra e no Brasil (1870-1920). História Econômica \& História de Empresas. v. 15, n. 2 (2012), p. 47-80.

SANTOS, João Manuel Casquinha Malaia e FORTES, Rafael. "Brasil-grande, estádios gigantescos": toponímia dos estádios públicos da ditadura civil-militar brasileira e os discursos de reconciliação. Tempo, Niterói. v. 27, n. 1, p. 166-183, 2021.

SILVA, Carlos Eduardo Lins da. Mil dias: os bastidores da revolução em um grande jornal. São Paulo: Trajetória Cultural, 1988.

SILVA, Fernanda Mauricio da. O Roda Viva e as estratégias de construção de um debate público. In: GOMES, Itania Maria Mota (org.) Gênero televisivo e modo de endereçamento no telejornalismo. Salvador: EDUFBA, 2011, pp. 49-74.

SOUZA, Juliano; MARCHI JUNIOR, Wanderley. Futebol bom é o Europeu?! Sobre as teses do atraso e do desvio na leitura do processo modernizador futebolístico brasileiro. In: GIGLIO, Sérgio Settani; PRONI, Marcelo Weishaupt. (Orgs.). O futebol nas ciências humanas no Brasil. Campinas: Editora da Unicamp, 2020.

TONINI, Marcel Diego; GIGLIO, Sérgio Settani. A transferência de jogadores no sistema FIFA e a migração de brasileiros para a Europa (1920-1970). Estudos Históricos. Rio de Janeiro, v. 32, n. 68, p. 609-632, 2019. 